\title{
Quantitative trait loci (QTLs) for water use and crop production traits co-locate with major QTL for tolerance to water deficit in a fine-mapping population of pearl millet (Pennisetum glaucum $\mathrm{L}$. R.Br.)
}

\author{
Murugesan Tharanya ${ }^{1,2} \cdot$ Jana Kholova ${ }^{1} \cdot$ Kaliamoorthy Sivasakthi $^{1,2} \cdot$ Deepmala Seghal $^{3} \cdot$ Charles Tom Hash $^{4}$.

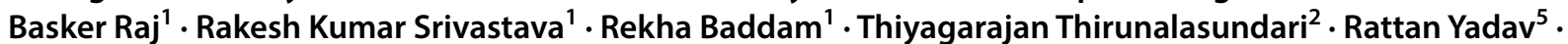 \\ Vincent Vadez ${ }^{1,6}$ (1)
}

Received: 24 November 2017 / Accepted: 8 April 2018

(c) Springer-Verlag GmbH Germany, part of Springer Nature 2018

\begin{abstract}
Key message Four genetic regions associated with water use traits, measured at different levels of plant organization, and with agronomic traits were identified within a previously reported region for terminal water deficit adaptation on linkage group 2. Close linkages between these traits showed the value of phenotyping both for agronomic and secondary traits to better understand plant productive processes.

Abstract Water saving traits are critical for water stress adaptation of pearl millet, whereas maximizing water use is key to the absence of stress. This research aimed at demonstrating the close relationship between traits measured at different levels of plant organization, some putatively involved in water stress adaptation, and those responsible for agronomic performance. A fine-mapping population of pearl millet, segregating for a previously identified quantitative trait locus (QTL) for adaptation to terminal drought stress on LG02, was phenotyped for traits at different levels of plant organization in different experimental environments (pot culture, high-throughput phenotyping platform, lysimeters, and field). The linkages among traits across the experimental systems were analysed using principal component analysis and QTL co-localization approach. Four regions within the LG02-QTL were found and revealed substantial co-mapping of water use and agronomic traits. These regions, identified across experimental systems, provided genetic evidence of the tight linkages between traits phenotyped at a lower level of plant organization and agronomic traits assessed in the field, therefore deepening our understanding of complex traits and then benefiting both geneticists and breeders. In short: (1) under no/mild stress conditions, increasing biomass and tiller production increased water use and eventually yield; (2) under severe stress conditions, water savings at vegetative stage, from lower plant vigour and fewer tillers in that population, led to more water available during grain filling, expression of stay-green phenotypes, and higher yield.
\end{abstract}

Electronic supplementary material The online version of this article (https://doi.org/10.1007/s00122-018-3094-6) contains supplementary material, which is available to authorized users.

Vincent Vadez

v.vadez@cgiar.org; vincent.vadez@ird.fr

1 Crop Physiology Laboratory, International Crops Research Institute for the Semi-Arid Tropics (ICRISAT), Patancheru, Telangana 502324, India

2 Bharathidasan University, Tiruchirappalli, Tamilnadu 620 024, India

3 International Center for Maize and Wheat Improvement (CIMMYT), Km. 45, Carretera Mex-Veracruz, El Batan, CP 56237 Texcoco, Mexico
4 ICRISAT Sahelian Center, Pearl Millet Breeding, International Crops Research Institute for the Semi-Arid Tropics (ICRISAT), BP 1204, Niamey, Niger

5 Institute of Biological, Environmental and Rural Sciences (IBERS), Aberystwyth University, Aberystwyth SY23 3EB, UK

6 Institut de Recherche pour le Developpement (IRD), Université de Montpellier, UMR DIADE, 911 Avenue Agropolis, BP 64501, 34394 Montpellier Cedex 5, France 


\section{Introduction}

Pearl millet [Pennisetum glaucum (L.) R.Br.] is the sixth most important global cereal crop (Sehgal et al. 2012) and an important source of livelihood for the subsistence of farming communities in the semi-arid tropics (SAT), providing food and feed to human population and cattle. It can produce significantly under water deficit/salinity/heat stress compared to other crops (Mahalakshmi et al. 1987; Krishnamurthy et al. 2007; Gupta et al. 2015). Though pearl millet can adapt to harsh environments, water deficit during the crop growth reduces its yield significantly (Mahalakshmi et al. 1987; Bidinger et al. 1987).

Efforts in the genetics of pearl millet adaptation to complex constraints have so far focused on the mapping of complex traits, generally using yield performance in targeted environments. However, crop adaptation mechanisms leading to crop production improvement under complex constraints, and their genetic relationships, are still poorly understood. In addition, the absence of tools to assess these mechanisms greatly hampers the progress in crop production improvement (Banziger and Cooper 2001). In the case of pearl millet's adaptation to drought stress, a variety of experimental systems have been used, i.e. field assessments targeting differences in panicle harvest index (PNHI) and yield (Bidinger et al. 1987); lysimeters (Vadez et al. 2011) to assess differences in the time profile of water use and its relationship to increased yield under terminal water deficit stress; the LeasyScan platform (Vadez et al. 2015) for a high-throughput assessment of differences in the canopy development; pot culture to assess differences in transpiration response to vapour pressure deficit (VPD) (Kholova et al. 2012). This work showed the importance of water saving traits, for instance the capacity of certain genotypes to restrict transpiration under high evaporative demand, to make more water available for the crucial grain filling period (Vadez et al. 2013a, b). In the current study, we combined these different phenotyping approaches, using a fine-mapping population segregating for traits related to drought stress adaptation, to understand the relationships among traits measured at different levels of plant organization and the role of these drought-adaptive mechanisms in agronomic performance.

Several mapping studies analysing the genetic basis of water deficit adaptation in pearl millet exist. A number of quantitative trait loci (QTLs) for grain and stover yield under terminal water deficit conditions have been identified (Yadav et al. 2002, 2003, 2004; Bidinger et al. 2007). Among these, a major QTL for yield under terminal drought was identified (Yadav et al. 2002) on pearl millet linkage group 2 (LG02) in two independent RIL populations (H 77/833-23 $\times$ PRLT 2/89-33 and ICMB 841 × ICMB 863B; Bidinger et al. 2005;
Serraj et al. 2005). An analysis of the same populations showed that several QTLs for drought-adaptive traits (related to plant water use; e.g. transpiration rate Tr; organ weights, leaf area and thickness) co-localized with the originally identified terminal drought tolerance QTL (LG) 02 (Kholova et al. 2012; Kakkera et al. 2015). However, phenotyping for traits related to plant water use in a large mapping population is time consuming. For instance, Kholova et al. (2012) used pot culture to phenotype the water use-related traits (transpiration response to VPD) manually, which involved measuring the leaf area of hundreds of plants destructively, and then could not measure canopy development and vigour, as this would require high-throughput techniques. Yet, these canopy traits also contribute to the plant water budget, i.e. smaller canopy potentially leading to lower water use (Vadez et al. 2013b). Also, the pot culture was not suitable for assessing the yield-related components. Therefore, in this work we investigate, compare, and link phenotyping outputs across various phenotyping systems; i.e. pot culture (Kholova et al. 2012), LeasyScan (Vadez et al. 2015), lysimeters (Vadez et al. 2011), and field (Bidinger et al. 2007) as each system complements the other systems. For example, canopy development traits were difficult to phenotype with pot culture and were then measured in the LeasyScan platform. Similarly, the water use traits were not measurable in the field and were then measured in lysimeters.

Hence, the overall objectives of this study were to (1) assess the variation in transpiration efficiency (TE) and the temporal pattern of transpiration using lysimeters; (2) develop functional understanding of associations between investigated traits through principal component analysis (PCA); (3) map QTLs for key traits related to plant water use and crop production traits using various phenotyping platforms; (4) assess the associations between plant water use components and plant production traits using a QTL colocalization approach; and (5) propose a crop improvement strategy accordingly.

\section{Materials and methods}

\section{Plant material: fine-mapping population (FMP)}

A major drought-tolerant QTL (DT-QTL) for water deficit adaptation in pearl millet was identified earlier by Yadav et al. (2002). The introgression of this QTL into H77/833-2 (high yielding, but poorly adapted to drought stress) showed yield benefits across water-limited environments (Serraj et al. 2005). Phenotyping and mapping of traits underlying this DT-QTL has pointed to water use parameters comapping in the DT-QTL region (Kholova et al. 2012). As 
the DT-QTL interval was large, a fine-mapping population (high-resolution cross) consisting of $\sim 2500$ individuals segregating specifically for DT-QTL interval on LG02 was developed by crossing the best-performing NILs of ICMR1029 with ICMR1004 (Sehgal et al. 2012; Yadav et al. 2010). This population was screened with six SSR markers (Xpsmp2237, Xpsmp2072, M13_Xpsmp2066, M13_Xpsmp3056, Xpsmp2206, and Xpsmp2059) and individuals were crossed with male sterile line $843 \mathrm{~A}$ to avoid inbreeding depression (Yadav et al. 2010). Later, 11 new SNP and CISP (conserved intron spanning primer) markers were added (Sehgal et al. 2012) and therefore 17 polymorphic markers were used for mapping QTLs. 162 lines having all combinations of crossing over between the markers were finally selected for the trials.

\section{Plant growth conditions and phenotyping}

In this work, the fine-mapping population (FMP) segregating within DT-LG02 was tested in four different phenotyping environments (Table 1 - experimental overview). In short, the pot experiment focused on the transpiration response to increases in VPD at a vegetative stage. The LeasyScan experiment focused on the canopy development and architecture characteristics at a vegetative stage, over a time frame or about 4 weeks. The lysimeter experiment provided a transpiration efficiency (TE) measurement over the entire crop cycle and gave a fine assessment of plant water use during the entire crop cycle, together with relevant yield and agronomic data to allow regression analysis. Finally, the field data provided an agronomic assessment of the progeny performance. Therefore, while there was some overlap among traits measured in the different experimental conditions, each of the measurement setups had its own specific targets. Also, many of the traits that were measured in each experimental setup were closely related to one another, and while these are mentioned in the text and summary statistics table, only the most representative traits were used in the QTL analysis. All experiments were conducted at PatancheruICRISAT campus (International Crops Research Institute for the Semi-Arid Tropics).

\section{Pot culture}

This experiment followed Kholova et al. (2012). The main focus was to assess the transpiration response to increasing VPD conditions. Traits linked to water use (transpiration, transpiration rate, leaf area, root weight, leaf weight, shoot weight-Table 1) were evaluated under well-watered conditions outdoors, in February, a period that usually exposes plants to high VPD in the afternoon. The average day/night VPD during plant growth was $3 \mathrm{kPa} / 0.90 \mathrm{kPa}$ with $32 / 24{ }^{\circ} \mathrm{C}$ and relative humidity $37 / 70 \%$. Four replications were grown and their sowing was staggered every 3-4 days to allow time for the trait measurement in each replication (see below). Sowing was done in four hills per pot and three to five seeds per hill, in $20 \mathrm{~cm}$-diameter pots. Plants were thinned to one plant per hill 1 week after sowing, and to two plants per pot 2 weeks after sowing. At the end of the second and final thinning, di-ammonium phosphate $\left(300 \mathrm{mg} \mathrm{kg}^{-1}\right.$ of soil) and urea (200 mg kg $\mathrm{mg}^{-1}$ of soil) were added. Individual replications were weighed on the fourth week after sowing in a way that plants of all replications had similar age at the time of weighing (Kholova et al. 2012). Pots were weighed three times, i.e. at 7:10 a.m., 10:10 a.m., and 2:10 p.m. to measure the transpiration $\left(\mathrm{g} \mathrm{h}^{-1}\right)$. These timings were chosen to assess the transpiration so that the measurements were done respectively in a period of low and high evaporative demand. The average low VPD was $1.87 \mathrm{kPa}$ (between 7:10 a.m. and 10:10) and the average high VPD was $3.56 \mathrm{kPa}$ between 10:10 a.m. and 2:10 p.m.). The pots were weighed following the same sequence so that the time between the pot weighing was identical for all pots. After the third weighing, pots were re-watered to field capacity and the same procedure was repeated the following day with the same set of plants. After the last weighing on the 2nd day, the plants were harvested and the leaf area (LA) was measured immediately using a leaf area meter (LI3000 model, Li-Cor, Lincoln, NE, USA). The leaf area was used to normalize the transpiration to calculate the transpiration rate $\left(\mathrm{g} \mathrm{cm}^{-2} \mathrm{~h}^{-1}\right)$. Root dry weight $(\mathrm{RDW})$, shoot dry weight $(\mathrm{ShDW}=\mathrm{LDW}+\mathrm{StDW})$, and total dry weight (TOTDW $=\mathrm{ShDW}+\mathrm{RDW}$ ) were also measured.

\section{High-throughput phenotyping platform: LeasyScan (LS)}

LeasyScan is an automated high-throughput phenotyping facility capturing traits related to the plant canopy development (for details see Vadez et al. 2015; http://www.gems. icrisat.org). The main focus was to assess the leaf area development and canopy architecture. Plants were grown under well-watered conditions in two experiments carried out in May 2015 and February 2016. Canopy development traits included the three-dimensional leaf area (3DLA, measured from the 3D images developed by the scanner), projected leaf area (unshaded leaf area), and canopy structure. Biomass traits included the biomass production and tiller count (Table 1). A measurement of the transpiration response to high VPD, similar to the pot setup above was also performed. Each replication/sector consisted of two $20 \mathrm{~cm}$ diameter pots, each with two plants after final thinning, in a sector area of $40 \times 65 \mathrm{~cm}$, i.e. approximately a quarter square meter. The pot contained $12 \mathrm{~kg}$ Alfisol collected from the ICRISAT farm. Planting and thinning were done as in the pot experiment above. Plant count was recorded after the final thinning. Plants were watered either early in the 
Table 1 Details on phenotypic traits collected from different setups (LeasyScan, pot culture, lysimeter, and field)

\begin{tabular}{|c|c|c|c|c|}
\hline Exp. setup & $\begin{array}{l}\text { Trait name and } \\
\text { trait code }\end{array}$ & $\begin{array}{l}\text { Year of } \\
\text { phenotyping }\end{array}$ & Rep & Treat \\
\hline \multirow[t]{9}{*}{ 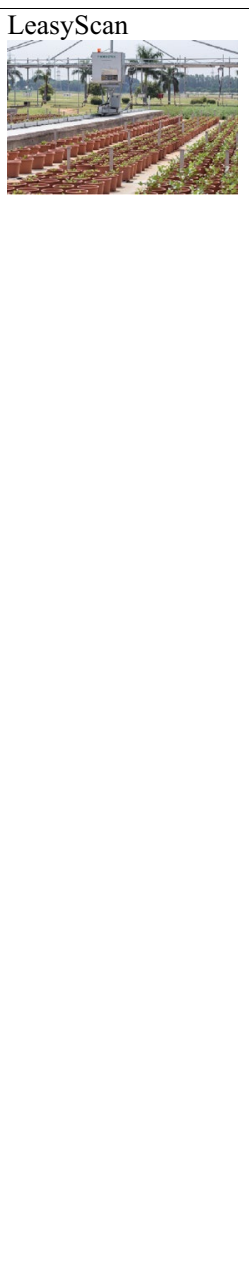 } & $\begin{array}{l}\text { Transpiration } \\
\left(\mathrm{g} \mathrm{h}^{-1}\right) ; \mathrm{T}-\mathrm{LS}\end{array}$ & $\begin{array}{l}2015 \text { (April- } \\
\text { May) and } \\
2016 \\
\text { (January- } \\
\text { February) }\end{array}$ & $\begin{array}{l}3 \\
\text { and } \\
4\end{array}$ & WW \\
\hline & $\begin{array}{l}\text { Transpiration rate } \\
\left(\mathrm{g} \mathrm{cm}^{-2} \mathrm{~h}^{-1}\right) ; \mathrm{Tr}- \\
\text { LS }\end{array}$ & $\begin{array}{l}2015 \text { (April- } \\
\text { May) and } \\
2016 \\
\text { (January- } \\
\text { February) }\end{array}$ & $\begin{array}{l}3 \\
\text { and } \\
4\end{array}$ & WW \\
\hline & $\begin{array}{l}\text { 3D leaf area } \\
\left(\mathrm{cm}^{2}\right) ; 3 \text { DLA-LS }\end{array}$ & $\begin{array}{l}2015 \text { (April- } \\
\text { May) and } \\
2016 \\
\text { (January- } \\
\text { February) }\end{array}$ & $\begin{array}{l}3 \\
\text { and } \\
4\end{array}$ & WW \\
\hline & $\begin{array}{l}\text { 3D leaf area } \\
\text { growth rate } \\
\left(\mathrm{cm}^{2} \text { day }^{-1}\right) \\
\text { 3DGR }\end{array}$ & $\begin{array}{l}2015 \text { (April- } \\
\text { May) and } \\
2016 \\
\text { (January- } \\
\text { February) }\end{array}$ & $\begin{array}{l}3 \\
\text { and } \\
4\end{array}$ & WW \\
\hline & $\begin{array}{l}\text { Canopy structure } \\
\left(\mathrm{cm}^{2}\right) ; \mathrm{CS}\end{array}$ & $\begin{array}{l}2015 \text { (April- } \\
\text { May) and } \\
2016 \\
\text { (January- } \\
\text { February) }\end{array}$ & $\begin{array}{l}3 \\
\text { and } \\
4\end{array}$ & WW \\
\hline & $\begin{array}{l}\text { Shoot dry weight } \\
\text { (g); ShDW-LS }\end{array}$ & $\begin{array}{l}2016 \\
\text { (January- } \\
\text { February) }\end{array}$ & 4 & WW \\
\hline & $\begin{array}{l}\text { Specific leaf } \\
\text { weight }\left(\mathrm{g} \mathrm{cm}^{-2}\right) \text {; } \\
\text { SLW-LS }\end{array}$ & $\begin{array}{l}2016 \\
\text { (January- } \\
\text { February) }\end{array}$ & 4 & WW \\
\hline & $\begin{array}{l}\text { Tiller number; } \\
\text { TNO-LS }\end{array}$ & $\begin{array}{l}2016 \\
\text { (January- } \\
\text { February) }\end{array}$ & 4 & WW \\
\hline & $\begin{array}{l}\text { Plant height }(\mathrm{cm}) \\
\text { PH }\end{array}$ & $\begin{array}{l}2015 \text { (April- } \\
\text { May) and } \\
2016 \\
\text { (January- } \\
\text { February) }\end{array}$ & $\begin{array}{l}3 \\
\text { and } \\
4\end{array}$ & WW \\
\hline \multirow[t]{6}{*}{ Pot culture } & Transpiration & 2010 & 4 & WW \\
\hline & $\begin{array}{l}\text { rate-morning } \\
\left(\mathrm{g} \mathrm{cm}^{-2} \mathrm{~h}^{-1}\right) \\
\text { TrM-P }\end{array}$ & $\begin{array}{l}\text { (January- } \\
\text { February) }\end{array}$ & & \\
\hline & $\begin{array}{l}\text { Transpiration } \\
\text { rate-evening } \\
\left(\mathrm{g} \mathrm{cm}^{-2} \mathrm{~h}^{-1}\right) \text {; TrE- } \\
\mathrm{P}\end{array}$ & $\begin{array}{l}2010 \\
\text { (January- } \\
\text { February) }\end{array}$ & 4 & WW \\
\hline & $\begin{array}{l}\text { Leaf area }\left(\mathrm{cm}^{2}\right) \\
\text { LA-P }\end{array}$ & $\begin{array}{l}2010 \\
\text { (January- } \\
\text { February) }\end{array}$ & 4 & WW \\
\hline & $\begin{array}{l}\text { Root dry weight } \\
\text { (g); RDW }\end{array}$ & $\begin{array}{l}2010 \\
\text { (January- } \\
\text { February) }\end{array}$ & 4 & WW \\
\hline & $\begin{array}{l}\text { Shoot dry weight } \\
\text { (g); ShDW-P }\end{array}$ & $\begin{array}{l}2010 \\
\text { (January- } \\
\text { February) }\end{array}$ & 4 & WW \\
\hline
\end{tabular}

Table 1 (continued)

\begin{tabular}{|c|c|c|c|c|}
\hline Exp. setup & $\begin{array}{l}\text { Trait name and } \\
\text { trait code }\end{array}$ & $\begin{array}{l}\text { Year of } \\
\text { phenotyping }\end{array}$ & Rep & Treat \\
\hline & $\begin{array}{l}\text { Total dry weight } \\
\text { (g); TOTDW-P }\end{array}$ & $\begin{array}{l}2010 \\
\text { (January- } \\
\text { February) }\end{array}$ & 4 & WW \\
\hline \multirow{13}{*}{ 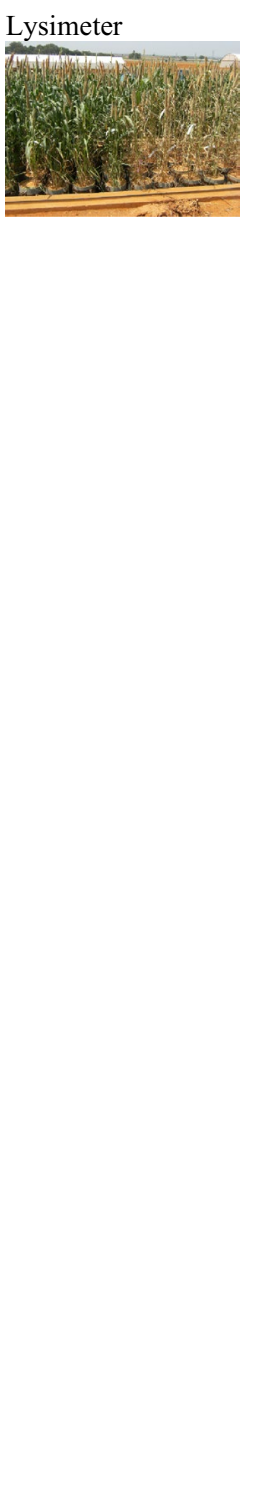 } & $\begin{array}{l}\text { Tiller number; } \\
\text { TNO-L }\end{array}$ & $\begin{array}{l}2011 \\
\text { (February- }\end{array}$ & 5 & WS \\
\hline & $\begin{array}{l}\text { Stay-green; STG- } \\
\text { L }\end{array}$ & $\begin{array}{l}2011 \\
\text { (February- } \\
\text { April) }\end{array}$ & 5 & WS \\
\hline & $\begin{array}{l}1000 \text { grain weight } \\
\text { (g); ThGW-L }\end{array}$ & $\begin{array}{l}2011 \\
\text { (February- } \\
\text { April) }\end{array}$ & 5 & WS \\
\hline & $\begin{array}{l}\text { Total panicle dry } \\
\text { weight }(\mathrm{g}) ; \\
\text { TOTPNDW }\end{array}$ & $\begin{array}{l}2011 \\
\text { (February- } \\
\text { April) }\end{array}$ & 5 & WS \\
\hline & $\begin{array}{l}\text { Total dry weight } \\
\text { (g); TOTDW-L }\end{array}$ & $\begin{array}{l}2011 \\
\text { (February- } \\
\text { April) }\end{array}$ & 5 & WS \\
\hline & $\begin{array}{l}\text { Grain yield } \\
\left(\text { g plant }^{-1}\right) ; G Y-L\end{array}$ & $\begin{array}{l}2011 \\
\text { (February- } \\
\text { April) }\end{array}$ & 5 & WS \\
\hline & $\begin{array}{l}\text { Transpiration- } \\
\text { 36DAS } \\
\left.\text { (g week }^{-1}\right) \text {; } \\
\text { T36DAS-L }\end{array}$ & $\begin{array}{l}2011 \\
\text { (February- } \\
\text { April) }\end{array}$ & 5 & WS \\
\hline & $\begin{array}{l}\text { Transpiration- } \\
\text { 41DAS } \\
\left(\text { g week }^{-1}\right) \\
\text { T41DAS-L }\end{array}$ & $\begin{array}{l}2011 \\
\text { (February- } \\
\text { April) }\end{array}$ & 5 & WS \\
\hline & $\begin{array}{l}\text { Transpiration- } \\
\text { 50DAS } \\
\left(\mathrm{g} \mathrm{week}^{-1}\right) \\
\text { 50DAS-L }\end{array}$ & $\begin{array}{l}2011 \\
\text { (February- } \\
\text { April) }\end{array}$ & 5 & WS \\
\hline & $\begin{array}{l}\text { Transpiration- } \\
\text { 57DAS } \\
\left(\text { g week }^{-1}\right) \text {; } \\
\text { T57DAS-L }\end{array}$ & $\begin{array}{l}2011 \\
\text { (February- } \\
\text { April) }\end{array}$ & 5 & WS \\
\hline & $\begin{array}{l}\text { Transpiration } \\
\text { 64DAS } \\
\left(\text { g week }^{-1}\right) \text {; } \\
\text { T64DAS-L }\end{array}$ & $\begin{array}{l}2011 \\
\text { (February- } \\
\text { April) }\end{array}$ & 5 & WS \\
\hline & $\begin{array}{l}\text { Transpiration } \\
\text { efficiency } \\
\left(\mathrm{g} \mathrm{mL}^{-1} \text { plant }^{-1}\right) \text {; } \\
\text { TE }\end{array}$ & $\begin{array}{l}2011 \\
\text { (February- } \\
\text { April) }\end{array}$ & 5 & WS \\
\hline & $\begin{array}{l}\text { Harvest index; } \\
\text { HI-L }\end{array}$ & $\begin{array}{l}2011 \\
\text { (February- } \\
\text { April) }\end{array}$ & 5 & WS \\
\hline \multirow{3}{*}{ 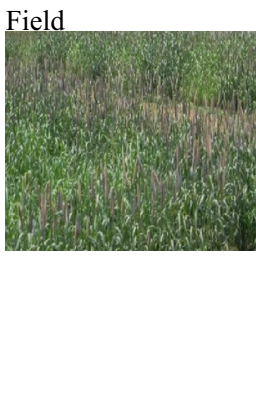 } & $\begin{array}{l}\text { Grain yield } \\
\left(\text { g plant }^{-1}\right) ; G Y-F\end{array}$ & $\begin{array}{l}2010 \text { and } \\
2011 \\
\text { (January- } \\
\text { April) }\end{array}$ & 4 & $\begin{array}{l}\text { WW } \\
\text { and } \\
\text { WS }\end{array}$ \\
\hline & $\begin{array}{l}\text { Harvest index } \\
(\%) ; \mathrm{HI}-\mathrm{F}\end{array}$ & $\begin{array}{l}2010 \text { and } \\
2011 \\
\text { (January- } \\
\text { April) }\end{array}$ & 4 & $\begin{array}{l}\text { WW } \\
\text { and } \\
\text { WS }\end{array}$ \\
\hline & $\begin{array}{l}\text { Time to flowering } \\
\text { (days); TF }\end{array}$ & $\begin{array}{l}2010 \text { and } \\
2011 \\
\text { (January- } \\
\text { April) }\end{array}$ & 4 & $\begin{array}{l}\text { WW } \\
\text { and } \\
\text { WS }\end{array}$ \\
\hline
\end{tabular}


Table 1 (continued)

\begin{tabular}{|c|c|c|c|c|}
\hline Exp. setup & $\begin{array}{l}\text { Trait name and } \\
\text { trait code }\end{array}$ & $\begin{array}{l}\text { Year of } \\
\text { phenotyping }\end{array}$ & Rep & Treat \\
\hline & $\begin{array}{l}\text { Panicle length } \\
\text { (cm); PL }\end{array}$ & $\begin{array}{l}2010 \text { and } \\
2011 \\
\text { (January- } \\
\text { April) }\end{array}$ & 4 & $\begin{array}{l}\text { WW } \\
\text { and } \\
\text { WS }\end{array}$ \\
\hline & $\begin{array}{l}\text { Panicle diameter } \\
(\mathrm{cm}) ; \mathrm{PD}\end{array}$ & $\begin{array}{l}2010 \text { and } \\
2011 \\
\text { (January- } \\
\text { April) }\end{array}$ & 4 & $\begin{array}{l}\text { WW } \\
\text { and } \\
\text { WS }\end{array}$ \\
\hline & $\begin{array}{l}\text { Tiller number } \\
\text { plant }^{-1} ; \text { TNO-F }\end{array}$ & $\begin{array}{l}2010 \text { and } \\
2011 \\
\text { (January- } \\
\text { April) }\end{array}$ & 4 & $\begin{array}{l}\text { WW } \\
\text { and } \\
\text { WS }\end{array}$ \\
\hline & $\begin{array}{l}\text { Total dry weight } \\
{\left(\text { g plant }^{-1}\right) \text {; }}_{\text {TOTDW-F }}\end{array}$ & $\begin{array}{l}2010 \text { and } \\
2011 \\
\text { (January- } \\
\text { April) }\end{array}$ & 4 & $\begin{array}{l}\text { WW } \\
\text { and } \\
\text { WS }\end{array}$ \\
\hline & $\begin{array}{l}1000 \text { grain weight } \\
\text { (g); ThGW(F) }\end{array}$ & $\begin{array}{l}2010 \text { and } \\
2011 \\
\text { (January- } \\
\text { April) }\end{array}$ & 4 & $\begin{array}{l}\text { WW } \\
\text { and } \\
\text { WS }\end{array}$ \\
\hline & $\begin{array}{l}\text { Grain number per } \\
\text { panicle; } \mathrm{GNPN}^{-1}\end{array}$ & $\begin{array}{l}2010 \text { and } \\
2011 \\
\text { (January- } \\
\text { April) }\end{array}$ & 4 & $\begin{array}{l}\text { WW } \\
\text { and } \\
\text { WS }\end{array}$ \\
\hline & $\begin{array}{l}\text { Stover dry matter } \\
\text { yield }\left(\text { g plant }^{-1}\right) \\
\text { SDMY }\end{array}$ & $\begin{array}{l}2010 \text { and } \\
2011 \\
\text { (January- } \\
\text { April) }\end{array}$ & 4 & $\begin{array}{l}\text { WW } \\
\text { and } \\
\text { WS }\end{array}$ \\
\hline
\end{tabular}

The images under the name of each system give the overview of the environment where the experiment was done

$W W$ well watered, $M S$ mild water stress, $S S$ severe water stress, Rep replication, Treat treatment

morning or late in the afternoon. Top dressing was done with di-ammonium phosphate $\left(300 \mathrm{mg} \mathrm{kg}^{-1}\right.$ of soil).

The scanning of the canopy started after the last thinning. Although the scanning took place every $2 \mathrm{~h}$, only one data point per day was extracted for 3DLA, projected LA, and plant height, corresponding to the maximum value within a $6 \mathrm{~h}$ window during the night (when scans were usually of the highest quality). A gravimetric assessment of plant transpiration in this setup consisted of weighing pots at 4 week after sowing of plant growth in both years. This was a procedure similar to the pot experiment above, except that the pots were not covered with beads and a plastic sheet to prevent soil evaporation. Pots were watered on the day before weighing to bring them to field capacity to ensure plants would not be limited by water during the experiment. Weighing was done in the morning (8:00-10:00 a.m.) and in the afternoon (3:00-5:00 p.m.) to measure evapotranspiration (ET). Soil evaporation was estimated from the leaf area index, so that the transpiration $(T ; \mathrm{g})$ value of each sector could be calculated from the evapotranspiration (ET; g). The estimation considered that soil evaporation $\left(E_{\mathrm{S}}\right)$ would be close to zero at a leaf area index (LAI) of 2, and would be equal to the evaporation of a bare soil $\left(E_{\mathrm{BS}}\right)$ at an LAI of 0 . Therefore, the soil evaporation of each sector $\left(E_{\mathrm{S}}\right)$ was proportional to the LAI so that:

$E_{\mathrm{S}}=(1-\mathrm{LAI} / 2) * E_{\mathrm{BS}}$.

By dividing $T$ with 3DLA, the transpiration rate (Tr; $\mathrm{g} \mathrm{cm}^{-2} \mathrm{~h}^{-1}$ ) was calculated. The 3DLA growth rate (3DGR; $\mathrm{cm}^{2}$ day $^{-1}$ ) was calculated during the exponential growth phase. The scanners measured both the 3DLA and the projected LA (PLA) and both parameters were closely related. However, in the PLA representing the vertical projection of the 3DLA on the ground, there was a degree of difference between these two indices that reflected somewhat the angular position of the leaves in the canopy. Therefore, PLA was regressed against the 3DLA and the residuals from the linear relationship between PLA and 3DLA were calculated as the difference between the observed PLA and the predicted PLA from the regression equation. For the sake of simplicity, these residuals were referred to as canopy structure (CS). With 3DLA as $X$-axis and PLA as $Y$-axis, large positive residuals, i.e. above the regression line, pointed to lines with wide leaf angles giving relatively large projected areas, whereas lines with large negative residuals represented lines with narrow leaf angle giving relatively small projected areas. Other parameters such as plant height $(\mathrm{PH}$; $\mathrm{cm}$ ) shoot dry weight (ShDW; g), tiller numbers (TNO), and specific leaf weight (SLW; $\mathrm{g} \mathrm{cm}^{-2}$ ) were also recorded and computed after harvest and drying of the plant samples.

\section{Lysimeter}

The protocol for growing and testing plants in lysimeters followed Vadez et al. (2013a). Lysimeters were used to assess transpiration efficiency (TE) and the time profile of plant water use over the entire crop cycle. The lysimeters also generated highly relevant agronomic crop traits. Four hills per PVC cylinder were sown on February 13, 2010, thinned to two plants per cylinder at 10 days after sowing, and finally to one plant per cylinder at 2 weeks after sowing. The experimental plants were harvested on April 29, 2010. The average day/night temperature during plant growth was $36 / 20{ }^{\circ} \mathrm{C}$ and relative humidity $30 / 75 \%$. Urea was applied as top dressing $\left(1.38 \mathrm{~g} \mathrm{~N}\right.$ plant $\left.^{-1}\right)$ at 28DAS. Plants were maintained under well-watered conditions until 28 days after sowing (DAS), each cylinder receiving $500 \mathrm{~mL}$ of water twice a week until 14DAS, and $500 \mathrm{~mL}$ of water on alternate days until 28DAS. At 28DAS, the soil in the cylinders was covered with polythene beads to prevent direct evaporation. Weighing was done at 28, 35, 41, 50, 57, and 64DAS. The last irrigation ( $2 \mathrm{~L}$ application per cylinder) was applied at 35DAS, corresponding to panicle emergence stage. Transpiration was calculated from differences in consecutive cylinder weights and water added between two consecutive weighings. Stay green (STG) was visually scored at 60DAS. At 76DAS plants were harvested and tiller number recorded. 
After drying in a hot air oven at $70{ }^{\circ} \mathrm{C}$ for 3 days, total panicle dry weight (including panicles from tillers), total aboveground dry weight, grain weight per plant (including tiller grain), and 1000-grain weight were recorded (Table 1). The harvest index (HI) was calculated as the ratio of grain weight to the total shoot biomass. Transpiration efficiency (TE) was calculated by dividing the total shoot biomass produced (panicle and vegetative tissues) by the total transpiration (28-64DAS). Here, the biomass prior to the initial weighing was not measured and then was not deducted from the TE assessment. It was assumed that the initial biomass was both small compared to the final biomass, and then that any genotypic difference in biomass at that stage would have been small, so that its influence on the absolute TE value would be small and the effect on the genotypic differences even smaller.

\section{Field}

Field experiments followed standard field management practices for millet cultivation (Bidinger et al. 1987). The crops were raised during the summer rain-free season (January-April of 2010 and 2011) with four replicated plots (2 rows of $4 \mathrm{~m}$ ) in an $\alpha$-lattice design with randomized blocks within each treatment. Three water stress treatments were used, i.e. fully irrigated, mild water stress, and severe water stress. The severe water stress treatment was imposed by stopping irrigation at the time of booting. The mild water stress treatment received one additional round of irrigation $(50 \mathrm{~mm}), 1$ week after the last one in the early stress treatment, and corresponding to the flowering stage. The well-watered (control) treatment received weekly irrigations until the end of grain filling. This experiment focused on the evaluation of crop production parameters, i.e. tiller numbers (TNO), grain yield (GY), 1000 grain weight (ThGW), grain number per panicle (GNPN), harvest index (HI), time to flowering (TF), panicle diameter (PD), and panicle length (PL). Grain yield was initially recorded as grain per plot and then calculated as grams per plant to make data more comparable to the lysimeter data. Harvest index (HI) was calculated as in the lysimeters. Panicle length (PL) and panicle diameter (PD) from the main shoot were measured (in $\mathrm{cm}$ ) at harvest. Tiller number (TNO) was recorded at harvest and included both productive and non-productive tillers. In this experiment, only 144 genotypes were tested, unlike the other above experiments where 162 genotypes were tested.

\section{Data analysis and statistics}

ANOVA (GenSTAT version 12) was employed to evaluate the range of variation for the traits within the experiments. Simple correlation (crop production-related traits from field) and principal component analysis (PCA) (princomp; R software) for the traits across different experimental environments were carried out to investigate the relationships among them. Firstly, the relationships between the traits from the field environment were analysed within each water treatment (well watered, WW; severe water stress, SS). Then to visualize the relationships between GY from field (both years) and traits from other environments, GY (SS) was compared with traits measured in the lysimeters (SS) and pot culture (WW) experiments. Then, GY (WW) was compared with traits measured in the LeasyScan (WW) experiment. In addition, possible relationships were tested between early water extraction (T36DAS and T41DAS) in the lysimeters (i.e. prior to water stress onset) and canopy development traits assessed in the LeasyScan platform (3DLA, PLA, 3DGR, PGR, CS and PH).

Finally, a composite interval mapping (CIM) study was used to evaluate and visualize the quantitative trait loci (QTLs) and their effect within the population using QTL cartographer (WinQTL 2.5). The experimental design opted for this mapping study was selfed intercross line (SF) and map function used was Haldane. BLUPs mean (GenSTAT version 12) were used for both PCA and composite interval mapping. Broad sense heritability was calculated using $h^{2}=\sigma_{\mathrm{G}}^{2} /\left(\sigma_{\mathrm{G}}^{2}+\sigma_{\mathrm{E}}^{2}\right)$, where $\sigma_{\mathrm{G}}^{2}$ is the genetic variance and $\sigma_{\mathrm{E}}^{2}$ is the error variance (Kholova et al. 2012) from GenSTAT (version 12). QTLs were given an LOD score and a PVE. The LOD score is indicative of the likelihood of linkage; LOD means the logarithm of odds, the 'odds' being the ratio of the probability that two loci are linked with a given recombination value over the probability that the two are not linked (Stam 1993) and PVE \% refers to the phenotypic variation percentage explained from that existing in a population.

Regarding the production traits from the field environment, there were high genotype-by-year-and-treatment interactions (Supplementary Table 1). Therefore, the mapping of production traits from the field was done individually for each year and treatment. Similarly, the mapping of traits from LeasyScan was done individually for two different years.

As explained earlier, the sowing of the four replications, each with 162 entries, was done in a staggered manner in the pot culture trial, with 3-4 days interval between the successive sowing of each replications, to ensure sufficient time for manual weighing and destructive leaf area measurements. When the BLUPs mean of all four replications were used for mapping purpose, no QTLs for any of the traits phenotyped was found. One of the reasons could be the differential effect of VPD on the plant growth and water use traits caused by staggered planting (Kholova et al. 2016). Many QTLs for canopy development, water use, and biomass traits were mapped when we used individual replications, as in Kholova et al. 2012 (see Supplementary Tables 2 and 3). However, the comparison of QTLs mapped across experimental setups was based on QTLs from BLUPs means. 


\section{Result}

\section{Transpiration efficiency (TE) variation and relationship with $\mathrm{GY}$}

Transpiration efficiency was significantly different among the genotypes under severe water stress (SS) in the lysimeters and genotypic means ranged from 3.43 to $4.50 \mathrm{~g} \mathrm{~kg}^{-1}$ with a mean value of $4.00 \mathrm{~g} \mathrm{~kg}^{-1}$. Regression analyses were done between TE, HI, and the grain yield (GY) (Fig. 1). The relationship between GY and $\mathrm{HI}$ was highly significant $\left(R^{2}=0.835 ; p<0.001\right)$. Since $\mathrm{GY}$ and $\mathrm{HI}$ are auto-correlative in nature (Vadez and Ratnakumar 2016) as GY is the part of $\mathrm{HI}$, the residual variations not related to HI were computed following previous work (Vadez et al. 2007), by calculating differences between the observed yield values and yield values that were derived from the regression equation between yield and HI. Residual yields were plotted against TE and post-anthesis water extraction (36-64DAS; Fig. 1). There was a significant positive correlation between residual GY variations with TE $\left(R^{2}=0.335 ; p<0.001\right)$ and post-anthesis water extraction $\left(R^{2}=0.17 ; p<0.05\right)$.

\section{Summary statistics}

The list of traits measured at different levels of plant organization in different phenotyping environments was classified and described according to their functionality and complexity: (1) canopy development traits (assessed mostly by LeasyScan), (2) water use traits (assessed by LeasyScan, pot culture, and lysimeters), (3) biomass and components (assessed by LeasyScan, lysimeters, and in field) and, (4) agronomic traits (assessed by lysimeters and in field).

\section{Canopy development traits}

The canopy development traits included 3D leaf area (3DLA), 3D leaf area growth rate (3DGR), canopy structure (CS), plant height $(\mathrm{PH})$, measured non-destructively with LeasyScan, and leaf area (LA) measured destructively in the pot culture experiment (details in Table 1). Most canopy development traits showed highly significant genotypic variations $(p<0.001)$ and high heritability (43-84\%). Traits measured with LeasyScan in 2015 showed significant variation, but not in 2016 (except PH with $59 \%$ heritability) (e.g. 3DLA, Fig. $2 \mathrm{a}-h^{2}=71 \%$ ). The destructive LA measured manually in the pot culture experiment did not show significant variation.

\section{Water use traits}

The water use traits were measured in LeasyScan $(T, \operatorname{Tr})$, pot culture (TrM and TrE), and in lysimeters (T36DAS,
T41DAS, T50DAS, T57DAS, T64DAS) (see details in Table 1). The traits measured through LeasyScan showed significant genotypic variation $(p<0.001)$ for 2015 and 2016 except $T$ in 2016. Transpiration rate in the morning ( $\operatorname{TrM}$ ) measured from pot culture and transpiration (T64DAS) during grain filling measured in lysimeters also showed significant genotypic variation $(p<0.001$ and $p<0.05$ respectively) with 32 and $27 \%$ heritability, respectively (Fig. 2).

\section{Biomass traits}

The biomass traits were measured through pot culture (TOTDW-P, RDW, ShDW-P), LeasyScan (ShDW-LS, SLW), lysimeter (TOTDW-L,), and in field (TOTDW-F, SDMY); see details (Table 1). Among these, several traits from LeasyScan (ShDW-LS, SLW), lysimeter (TOTDWL), and field (TOTDW-F $2010 \mathrm{WW} ; 2011$ SS, SDMY 2010 WW and MS) showed significant $(p<0.05)$ genotypic variation with moderate heritability (20-29\%; Table 2$)$. The significant range of variation $(p<0.05)$ obtained for TOTDW$\mathrm{F}$ in 2010 with $25 \%$ heritability under WW is shown in Fig. 2c.

\section{Crop production traits}

The production traits were measured from LeasyScan (TNO), lysimeters (TNO, ThGW, TOTPNDW, GY, and HI), and field (GY, TF, PL, PD, TNO, HI, ThGW, and GNPN ${ }^{-1}$ ) (see details in Table 1). Most of the production traits showed significant genotypic variation $(p<0.001)$ with different water stress treatments and years (Table 2). Among them, the traits from field, i.e. ThGW in 2011 (88\% heritability in WW and $85 \%$ in MS) and 2010 (87\% heritability in MS), and TF in 2011 (MS; 87\% heritability) had the highest heritability of all traits. The significant range of variation $(p<0.001)$ obtained for GY from field in 2010 under MS with $37 \%$ heritability is shown in Fig. 2 d.

\section{Principal component analyses (PCA)}

Several PCAs were carried out to analyse trait association within and between trials. The initial two PCAs focused on individual treatment in the field (WW, Fig. 3a; SS, Fig. 3b) and then the remaining PCAs progressively linked the grain yield from the field to trait measurements in the other experimental setups to illustrate trait associations (Fig. 3e-f). Data on GY from field (SS) and traits from lysimeters (SS) are combined in Fig. 3c; data on GY from field (WW) and traits from high-throughput phenotyping platform (WW) are combined in Fig. 3d; data on GY from the field (SS) and traits from pot culture (WW) are combined in Fig. 3e. Finally, traits on early water extraction (T36DAS and T41DAS) from lysimeters (SS) 

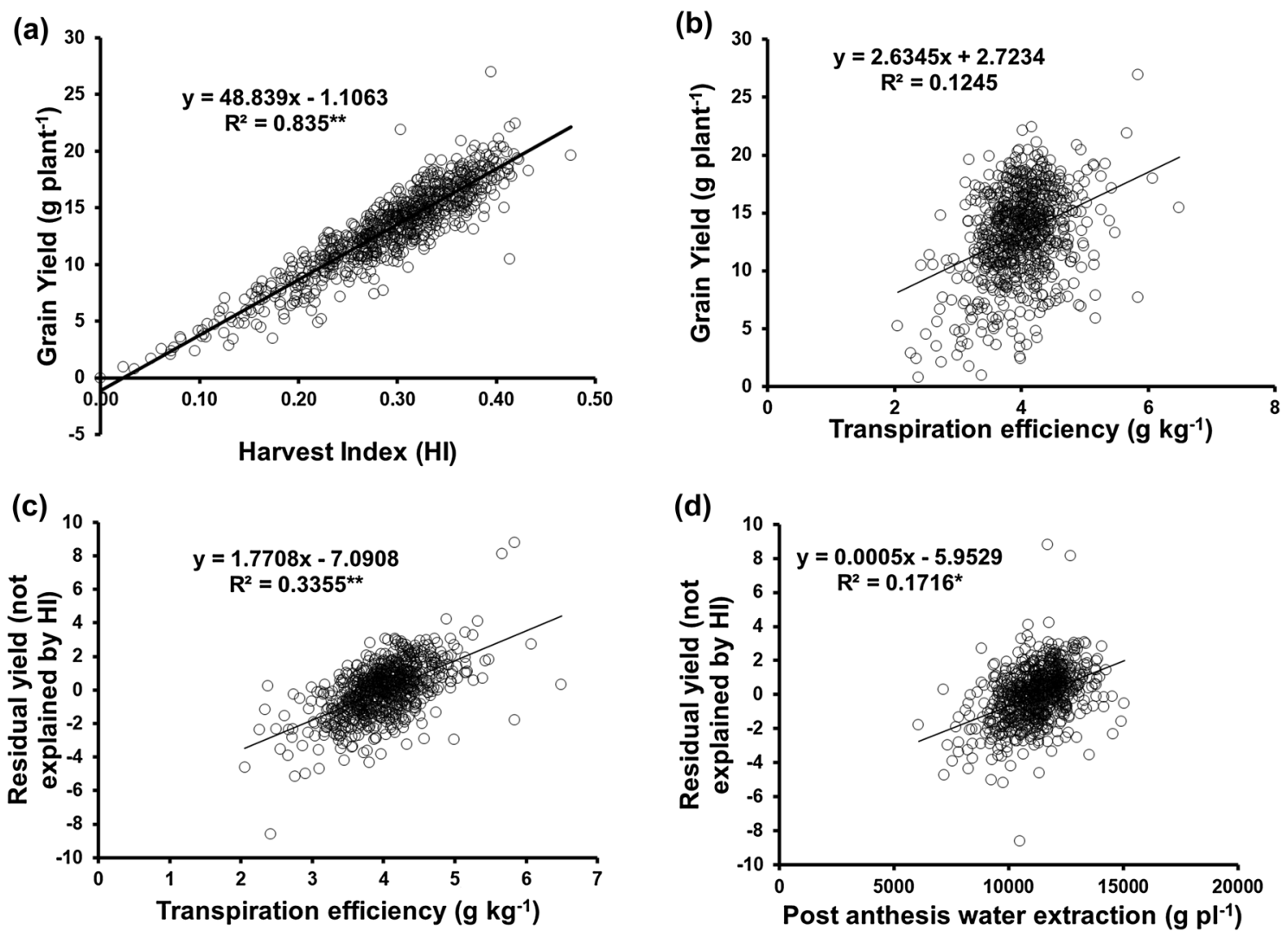

Fig. 1 Relationships between: a grain yield (g plant $\left.{ }^{-1}\right)$ and harvest index; b grain yield $\left(\mathrm{g} \mathrm{plant}^{-1}\right)$ and transpiration efficiency $\left(\mathrm{g} \mathrm{kg}^{-1}\right)$; c residual yield not explained by the harvest index (calculated from regression equations of a) and transpiration efficiency; and d residual yield not explained by the harvest index and post-anthesis

and canopy development-related traits (3DLA, 3DGR, PH) from LeasyScan (WW) are combined in Fig. 3f.

In the field environment, the first three components explained 69\% (2010) and 70\% (2011) of the variability under WW, 68\% (2010) and 74\% (2011) variability under MS, and 74 and 75\% (2010 and 2011) under SS (Supplementary Table 1). Increase in tiller numbers (TNO) favoured grain yield under WW, but not under SS (GY; Fig. 3a), both in the field (Fig. 3b) and in the lysimeters (Fig. 3c).

Under SS, when the GY from both the years was combined with the traits from the lysimeters, GY from both 2010 and 2011 increased with increase in water uptake during grain filling, i.e. transpiration at 50DAS, 57DAS, and 64DAS (Fig. 3c). Interestingly, GY from field under SS (2011) increased with STG scores taken at 60DAS (Fig. 3c), which in turn were very closely related to late water extraction (transpiration at 64DAS), confirming earlier findings of a close relationship between stay green and water availability during the grain filling period in pearl millet (Vadez et al. 2013a). The TOTDW from lysimeters increased with increase in TE under SS (Fig. 3c). In addition, water

water extraction $\left(\mathrm{g} \mathrm{plant}^{-1}\right)$. Data were obtained from the lysimeter trial. Data are individual replication values for each of the five replicated plants per genotype under severe water stress treatment. * and $* *$ indicate the significant difference statistically at $p<0.05$ and $p<0.001$, respectively

extraction in the early stage of crop development (T36DAS and T41DAS) was negatively correlated to late water extraction (T50DAS, T57DAS, and T64DAS). This suggested that larger plants with higher water extraction early in their cycle tended to run short of water later on during grain filling, confirming earlier similar findings in sorghum (Vadez et al. 2011) and chickpea (Zaman-Allah et al. 2011a). This was also supported by the observation of a close relationship between TOTDW and early water use. The yield advantage of smaller plants that do not run out of water immediately seems to be reflected in the observation that GY is related to late water use. Hence, the observed differences in water extraction could be in part determined by plant size.

When the GY from field under WW was combined with LeasyScan traits (WW), GY from the 2010 field trial increased with increased value in canopy structure (CS) and GY from 2011 field trial increased with increase in tiller number (TNO; Fig. 3d). High CS value would indeed reflect lines with a large canopy cover coming possibly from wide leaf angles, giving a likely early ground cover, which led to higher transpiration and higher yield. A strong negative correlation was found between 


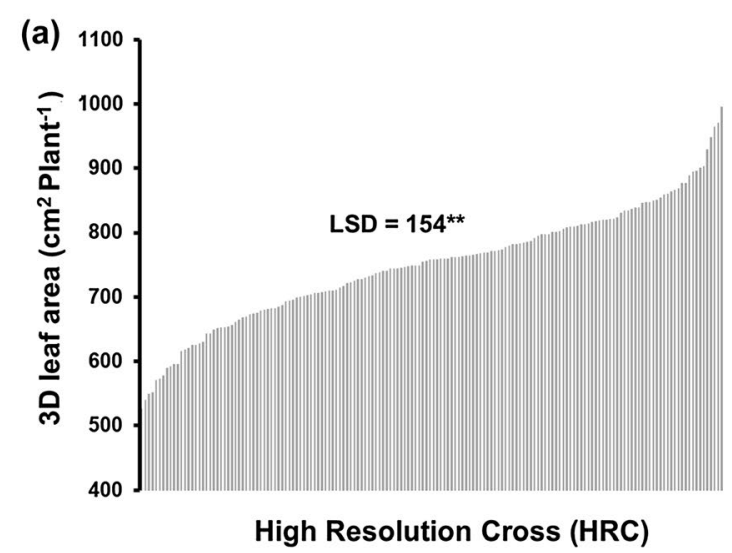

(c)

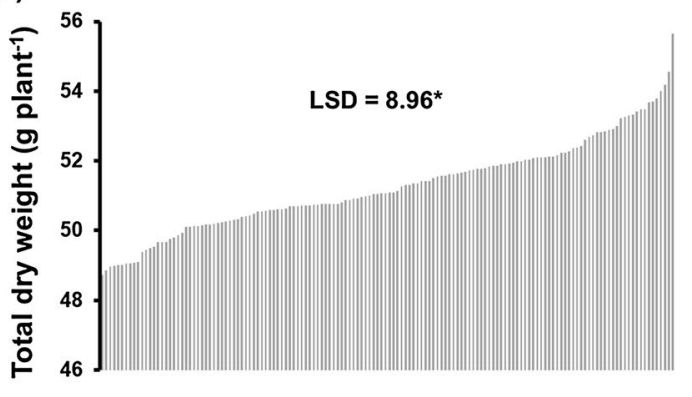

High Resolution cross (HRC)
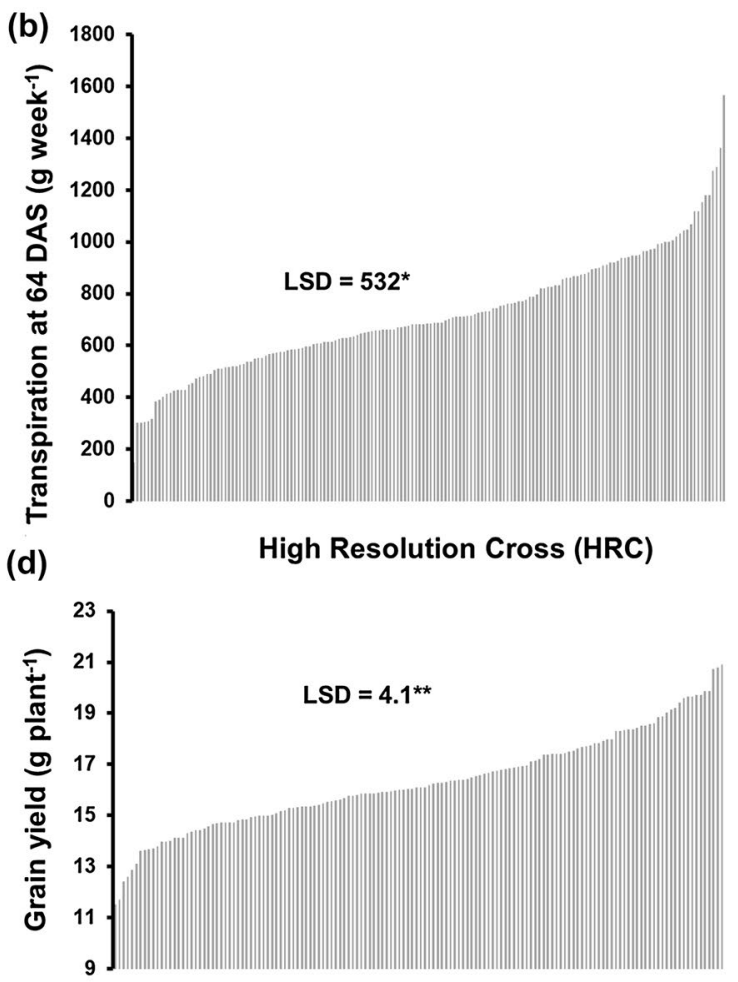

High Resolution Cross (HRC)

MS). Data were obtained from the lysimeter trial. * and $* *$ indicate the significant difference statistically at $p<0.05$ and $p<0.001$, respectively

Based on the PCA analysis, the traits that showed associations across different experiments were selected for further QTL analysis.

\section{QTL mapping}

Quantitative trait loci mapping revealed that most mapped traits fell within four main genetic regions within the fine-mapped region in LG02. Therefore for simplicity, the genetic regions are further referred to as follows: region1 (R1) covers from 191 to $205 \mathrm{cM}$, region2 (R2) from 229 to $233 \mathrm{cM}$, region3 (R3) from 236 to $240 \mathrm{cM}$, and region4 (R4) from 251 to $259 \mathrm{cM}$.

\section{QTL mapping for canopy development traits}

For canopy development-related traits (PH, CS), four major QTLs were identified. One major QTL for PH was mapped in both 2015 (LOD 3.4 and PVE 52\%) and 2016 (LOD 3.8 and PVE 14\%) in R4 and R3, respectively (Table 3). The other two major QTLs were mapped for CS in both 2015 (LOD 10.8 and PVE 32\%) and 2016 (LOD 3.1 and PVE $10 \%$ ) in R1 (Table 3). The alleles for the canopy development traits were contributed by both ICMR1029 and ICMR1004 (Fig. 4). 
Table 2 ANOVA results of traits (canopy development, water use, biomass, and grain production related) measured in different environments

\begin{tabular}{|c|c|c|c|c|c|c|c|c|c|}
\hline Trait & Traits & Year & Treatment & Minimum & Maximum & Mean & LSD & Significance & $\begin{array}{l}\text { Herit- } \\
\text { ability } \\
(\%)\end{array}$ \\
\hline \multirow[t]{9}{*}{ Canopy development } & 3DGR-LS & 2015 & WW & 229.47 & 557.51 & 386.61 & 46.55 & $<0.001$ & 84 \\
\hline & 3DGR-LS & 2016 & WW & 22.37 & 163.46 & 97.97 & 25.15 & ns & - \\
\hline & 3DLA-LS & 2015 & WW & 445.14 & 1100.73 & 757.99 & 153.85 & $<0.001$ & 71 \\
\hline & 3DLA-LS & 2016 & WW & 214.54 & 2422.23 & 1130.82 & 276.5 & ns & - \\
\hline & CS-LS & 2015 & WW & -406.6 & 94.88 & -201.39 & 48.29 & $<0.001$ & 43 \\
\hline & CS-LS & 2016 & WW & -123.99 & 102.44 & -0.01 & 45.13 & ns & - \\
\hline & LA-P & 2010 & WW & 130.53 & 1658.59 & 829.26 & 368.4 & ns & - \\
\hline & PH-LS & 2015 & WW & 98.28 & 190.35 & 145.1 & 21.75 & $<0.001$ & 70 \\
\hline & PH-LS & 2016 & WW & 130.17 & 313.33 & 220.02 & 36.04 & $<0.001$ & 59 \\
\hline \multirow[t]{13}{*}{ Water use } & STG-60DAS & 2011 & SS & 1.6 & 2.6 & 2.1 & 1.8 & $<0.05$ & 25 \\
\hline & T-36DAS-L & 2011 & SS & 360 & 3520 & 1973.33 & 728.8 & ns & - \\
\hline & T-41DAS-L & 2011 & SS & 160 & 4200 & 2808.36 & 740.9 & ns & - \\
\hline & T-50DAS-L & 2011 & SS & 120 & 4640 & 3340.26 & 776.6 & ns & - \\
\hline & T-57DAS-L & 2011 & SS & 200 & 3580 & 2094.14 & 877.4 & ns & - \\
\hline & T-64DAS-L & 2011 & SS & 100 & 1880 & 718.26 & 531.5 & $<0.05$ & 27 \\
\hline & TE-L & 2011 & SS & 3.43 & 4.5 & 4 & 0.63 & ns & - \\
\hline & T-LS & 2015 & WW & 76.33 & 203.33 & 157.6 & 129.39 & $<0.001$ & 67 \\
\hline & T-LS & 2016 & WW & 21.13 & 229.56 & 110.11 & 46.36 & ns & - \\
\hline & TrE-P & 2010 & WW & 0.02 & 0.08 & 0.06 & 0 & ns & - \\
\hline & Tr-LS & 2015 & WW & 0.11 & 0.48 & 0.26 & 25.03 & $<0.001$ & 79 \\
\hline & Tr-LS & 2016 & WW & 0.02 & 0.24 & 0.11 & 0.05 & $<0.05$ & 30 \\
\hline & TrM-P & 2010 & WW & 0.01 & 0.02 & 0.01 & 0 & $<0.001$ & 32 \\
\hline \multirow[t]{12}{*}{ Biomass } & RDW-P & 2010 & WW & 0.54 & 6.01 & 2.44 & 1.3 & ns & - \\
\hline & ShDW-LS & 2016 & WW & 8.23 & 89.69 & 40.17 & 14.28 & $<0.05$ & 29 \\
\hline & ShDW-P & 2011 & WW & 1.01 & 10.41 & 5.9 & 2.27 & ns & - \\
\hline & SLW-LS & 2016 & WW & 0.01 & 0.11 & 0.04 & 0.02 & $<0.05$ & 25 \\
\hline & TOTDW-F & 2010 & WW & 30.64 & 64.77 & 50.63 & 8.96 & $<0.05$ & 25 \\
\hline & TOTDW-F & 2010 & SS & 23.09 & 45.17 & 33.52 & 6.87 & ns & - \\
\hline & TOTDW-F & 2010 & MS & 27.84 & 56.28 & 41.94 & 9.11 & ns & - \\
\hline & TOTDW-F & 2011 & WW & 36.83 & 70.35 & 52.97 & 9.13 & ns & - \\
\hline & TOTDW-F & 2011 & SS & 20.28 & 44.09 & 33.22 & 6.63 & $<0.05$ & 20 \\
\hline & TOTDW-F & 2011 & MS & 24.29 & 54.15 & 41.63 & 8 & ns & - \\
\hline & TOTDW-P & 2010 & WW & 1.85 & 13.87 & 8.36 & 3.09 & ns & - \\
\hline & TOTDW-L & 2011 & SS & 10.65 & 31.2 & 22.95 & 4.72 & ns & - \\
\hline \multirow[t]{10}{*}{ Crop production } & $\mathrm{GNPN}^{-1}-\mathrm{F}$ & 2010 & WW & 533 & 1144 & 841.29 & 144.9 & $<0.001$ & 51 \\
\hline & $\mathrm{GNPN}^{-1}-\mathrm{F}$ & 2010 & SS & 286 & 727 & 509.92 & 117.4 & $<0.001$ & 40 \\
\hline & $\mathrm{GNPN}^{-1}-\mathrm{F}$ & 2010 & MS & 320 & 927 & 689.15 & 133.1 & $<0.001$ & 56 \\
\hline & $\mathrm{GNPN}^{-1}-\mathrm{F}$ & 2011 & WW & 555 & 1133 & 897.94 & 129.5 & $<0.001$ & 61 \\
\hline & $\mathrm{GNPN}^{-1}-\mathrm{F}$ & 2011 & SS & 305 & 780 & 544.46 & 124.3 & $<0.001$ & 57 \\
\hline & $\mathrm{GNPN}^{-1}-\mathrm{F}$ & 2011 & MS & 481 & 942 & 711.17 & 127.8 & $<0.001$ & 39 \\
\hline & GY-F & 2010 & WW & 11.69 & 29.19 & 22.21 & 4.21 & $<0.001$ & 29 \\
\hline & GY-F & 2010 & SS & 4.25 & 13.81 & 8.86 & 2.69 & $<0.001$ & 32 \\
\hline & GY-F & 2010 & MS & 9.41 & 23.14 & 16.25 & 4.1 & $<0.001$ & 37 \\
\hline & GY-F & 2011 & WW & 13.43 & 28.7 & 21.38 & 3.94 & $<0.001$ & 35 \\
\hline
\end{tabular}


Table 2 (continued)

\begin{tabular}{|c|c|c|c|c|c|c|c|c|c|}
\hline Trait & Traits & Year & Treatment & Minimum & Maximum & Mean & LSD & Significance & $\begin{array}{l}\text { Herit- } \\
\text { ability } \\
(\%)\end{array}$ \\
\hline & GY-F & 2011 & SS & 4.3 & 12.36 & 8.2 & 2.14 & $<0.001$ & 60 \\
\hline & GY-F & 2011 & MS & 8.29 & 19.23 & 13.81 & 3.17 & $<0.05$ & 28 \\
\hline & GY-L & 2011 & SS & 0.79 & 20.47 & 13.19 & 4.53 & $\mathrm{~ns}$ & - \\
\hline & PD-F & 2010 & WW & 2.18 & 2.68 & 2.46 & 0.15 & $\mathrm{~ns}$ & - \\
\hline & PD-F & 2010 & SS & 2.08 & 2.66 & 2.41 & 0.15 & $<0.001$ & 48 \\
\hline & PD-F & 2010 & MS & 2.17 & 2.78 & 2.55 & 0.14 & $<0.001$ & 50 \\
\hline & PD-F & 2011 & WW & 2.32 & 2.75 & 2.57 & 0.11 & $<0.001$ & 43 \\
\hline & PD-F & 2011 & SS & 1.94 & 2.6 & 2.34 & 0.17 & ns & - \\
\hline & PD-F & 2011 & MS & 2.13 & 2.83 & 2.43 & 0.16 & $<0.05$ & 31 \\
\hline & PL-F & 2010 & WW & 16 & 22 & 19.81 & 1.31 & $<0.001$ & 53 \\
\hline & PL-F & 2010 & SS & 17 & 22 & 20.12 & 1.49 & $<0.001$ & 37 \\
\hline & PL-F & 2010 & MS & 16.67 & 22.33 & 20.22 & 1.34 & $<0.001$ & 48 \\
\hline & PL-F & 2011 & WW & 18 & 21 & 20.14 & 0.98 & ns & - \\
\hline & PL-F & 2011 & SS & 17 & 21 & 19.73 & 1.21 & ns & - \\
\hline & PL-F & 2011 & MS & 18 & 23 & 20.38 & 1.04 & $<0.001$ & 52 \\
\hline & PNHI-F & 2010 & WW & 58.23 & 76.92 & 70.39 & 4.08 & $<0.001$ & 38 \\
\hline & HI-F & 2010 & WW & 0.34 & 0.49 & 0.44 & 0.04 & ns & - \\
\hline & HI-F & 2010 & SS & 0.16 & 0.34 & 0.26 & 0.05 & $<0.001$ & 59 \\
\hline & HI-F & 2010 & MS & 0.24 & 0.48 & 0.39 & 0.06 & $<0.001$ & 54 \\
\hline & HI-F & 2011 & WW & 0.33 & 0.45 & 0.4 & 0.03 & $<0.001$ & 39 \\
\hline & HI-F & 2011 & SS & 0.16 & 0.32 & 0.24 & 0.04 & $<0.001$ & 74 \\
\hline & HI-F & 2011 & MS & 0.23 & 0.39 & 0.33 & 0.04 & $<0.001$ & 69 \\
\hline & HI-L & 2011 & SS & 0.12 & 0.83 & 0.61 & 0.12 & $<0.001$ & 77 \\
\hline & TF-F & 2010 & WW & 33 & 38 & 36.2 & 1.18 & $<0.001$ & 81 \\
\hline & TF-F & 2010 & SS & 33 & 38 & 35.76 & 1.28 & $<0.001$ & 76 \\
\hline & TF-F & 2010 & MS & 33 & 38 & 36.36 & 1.04 & $<0.001$ & 82 \\
\hline & TF-F & 2011 & WW & 40 & 46 & 43.4 & 1.68 & $<0.001$ & 41 \\
\hline & TF-F & 2011 & SS & 40 & 46 & 43.58 & 1.45 & $<0.001$ & 81 \\
\hline & TF-F & 2011 & MS & 40 & 46 & 43.27 & 1.39 & $<0.001$ & 87 \\
\hline & ThGW-F & 2010 & WW & 7.48 & 10.55 & 9.12 & 0.63 & $<0.001$ & 83 \\
\hline & ThGW-F & 2010 & SS & 4.88 & 8.33 & 6.72 & 0.73 & $<0.001$ & 80 \\
\hline & ThGW-F & 2010 & MS & 6.63 & 10.13 & 8.59 & 0.61 & $<0.001$ & 87 \\
\hline & ThGW-F & 2011 & WW & 8.08 & 11.28 & 9.78 & 0.57 & $<0.001$ & 88 \\
\hline & ThGW-F & 2011 & SS & 4.6 & 8.7 & 6.81 & 0.87 & $<0.001$ & 80 \\
\hline & ThGW-F & 2011 & MS & 5.98 & 9.75 & 8.09 & 0.72 & $<0.001$ & 85 \\
\hline & ThGW-L & 2011 & SS & 0 & 8.37 & 5.8 & 1.39 & $<0.001$ & 41 \\
\hline & TNO-F & 2010 & WW & 1.55 & 3.93 & 2.89 & 0.74 & ns & - \\
\hline & TNO-F & 2010 & SS & 1.52 & 3.36 & 2.55 & 0.58 & ns & - \\
\hline & TNO-F & 2010 & MS & 1.48 & 3.77 & 2.75 & 0.66 & $<0.05$ & 26 \\
\hline & TNO-F & 2011 & WW & 1.5 & 3.24 & 2.44 & 0.45 & $<0.001$ & 42 \\
\hline & TNO-F & 2011 & SS & 1.33 & 3 & 2.21 & 0.47 & $<0.001$ & 54 \\
\hline & TNO-F & 2011 & MS & 1.3 & 3.46 & 2.43 & 0.5 & $<0.001$ & 41 \\
\hline
\end{tabular}


Table 2 (continued)

\begin{tabular}{llllllllll}
\hline Trait & Traits & Year & Treatment & Minimum & Maximum & Mean & $\begin{array}{c}\text { LSD } \\
\text { Significance }\end{array}$ & $\begin{array}{l}\text { Herit- } \\
\text { ability } \\
(\%)\end{array}$ \\
\hline & & & & & & & & & \\
& TNO-L & 2011 & SS & 2 & 8 & 4.81 & 1.55 & $<0.001$ & 19 \\
& TNO-LS & 2016 & WW & 3.5 & 13 & 7.6 & 2.24 & $<0.001$ & 36 \\
& TOTPNDW-L & 2011 & SS & 3.57 & 29.06 & 20.45 & 5.37 & ns & - \\
\hline
\end{tabular}

The environment used for phenotyping each trait is indicated by suffix letters; P-pot culture; LS—LeasyScan; L-lysimeter and F-field $L S D$ least significant difference, $W W$ well watered, $M S$ mild water stress, $S S$ severe water stress, $n s$ non-significant. Refer to Table 1 for the acronym of the traits

\section{QTL mapping for water use-related traits}

For water use traits ( $T$, Tr, STG), a total of 6 QTLs (both major and minor) were identified. Among these, four major QTLs explaining $10-37 \%$ of phenotypic variation were mapped in R1 (2 QTLs), R3 (1 QTL), and R4 (1 QTLs) (Table 3). For these same traits, two minor QTLs explaining $2-6 \%$ of the phenotypic variation each were identified in R2 and R4 (Supplementary Table 4).

Mapping details of water use-related traits in LeasyScan and lysimeters are provided in Table 3 and Supplementary Table 4. In the lysimeter system, STG trait had one major QTL (LOD 3.3 and PVE 10\%) in R3 (Table 3). In 2015, two major QTLs for $T$ (LOD 3.4 and 4.9 and PVE 27-37\%) were mapped in R1 and R4 (Table 3). T57DAS had one minor QTL (LOD 2.8 and PVE 6\%) mapped in R2 (Supplementary Table 4). For Tr, one major QTL (LOD 2.8 and PVE 13\%) was mapped in R1 (Table 3) and another minor QTL (LOD 2.5 and PVE 2\%) was mapped in R4 (Supplementary Table 4). The positive alleles for the water use-related traits were inherited from both ICMR1029 and ICMR1004 (Fig. 4).

\section{QTL mapping for biomass traits}

For these traits, four QTLs were found across different experimental systems. For SLW, two major QTLs (LOD 4.7 and 12.6 and PVE 40 and 55\%) were mapped in R1 and R4 (Table 3). For TOTDW, two minor QTLs (LOD 4.2-2.6 and PVE 6-8\%) were mapped in R2 and R3 (Supplementary Table 4). Most of the positive alleles for biomass-related traits were contributed by ICMR1004 (Fig. 4).

\section{QTL mapping for crop production traits}

For these traits, 15 QTLs were identified in three different systems (LeasyScan, lysimeters, and field systems). Among these, 11 major QTLs (LOD 2.6-7.6 and PVE 10-43\%) were mapped in R2, R3, and R4 and also in the regions between
R1 and R2; R3, and R4 (Table 3). The remaining four minor QTLs (LOD 2.6-2.8 and PVE up to 9\%) were mapped in the region between R1 and R2 (Supplementary Table 4). For GY, four major QTLs (LOD 3.1-8.0 and PVE 10-43\%) were identified all under SS in the regions of R2, R3, and R4. For TNO, seven major QTLs (LOD 3.1-6.4 and PVE $12-17 \%$ ) were mapped in the region of $\mathrm{R} 2, \mathrm{R} 3$, and in the region between R1 and R2. One minor QTL (LOD 2.7 and PVE 9\%) was also found in the region between R1 and R2.

Simple correlation analysis showed that most of the parameters from the field were closely related under specific water stress treatment in both the years (Tables 4, 5).

\section{QTL co-localization}

In the R1 region, most of the QTLs for traits relating to canopy development, water use, and few biomass and crop production traits (mostly under WW and MS in the field) co-located. Similarly, in the R4 region, QTLs for traits related to canopy development, water use, and crop production traits (mostly under SS in the field) co-located. In the R3 region, few QTLs for crop production traits co-located with biomass, canopy development $(\mathrm{PH})$, and water use (STG)-related traits. Under WW and MS, the QTLs for GY co-located with CS. The QTLs for grain yield (MS) and T57DAS (SS) co-located with each other. In addition, the QTLs for GY from lysimeters (SS) co-located with the QTLs for STG. Interestingly, most of the positive alleles for the crop production traits under SS were contributed by ICMR1029, although alleles from both ICMR1029 and ICMR 1004 contributed more or less equally under WW and MS (Fig. 4).

\section{Discussion}

In this study, we first identified a number of trait relationships across levels of biological organization with the PCA analysis. For instance, plant size conditioned the rate of 
Fig. 3 Principal component analysis for: a field traits under WW; b field traits under SS; c grain yield from field (SS) and traits from lysimeter (SS); d grain yield from field (WW) and traits from LeasyScan (WW); e grain yield from field (SS) and traits from pot culture (WW); and $\mathbf{f}$ early water extraction '(T36DAS and T41DAS) from lysimeter SS)' and canopy development related traits (3DLA, PLA, 3DGR, PGR, CS and $\mathrm{PH}$ ) from LeasyScan under WW. The suffix to the trait code indicates the environment (F-field, L-lysimeter, LSLeasyScan, P-pot) followed by the year of phenotyping and water stress treatment ( $W W$ well watered, $M S$ mild water stress, $S S$ severe water stress). Refer to Table 1 for the acronym of the traits
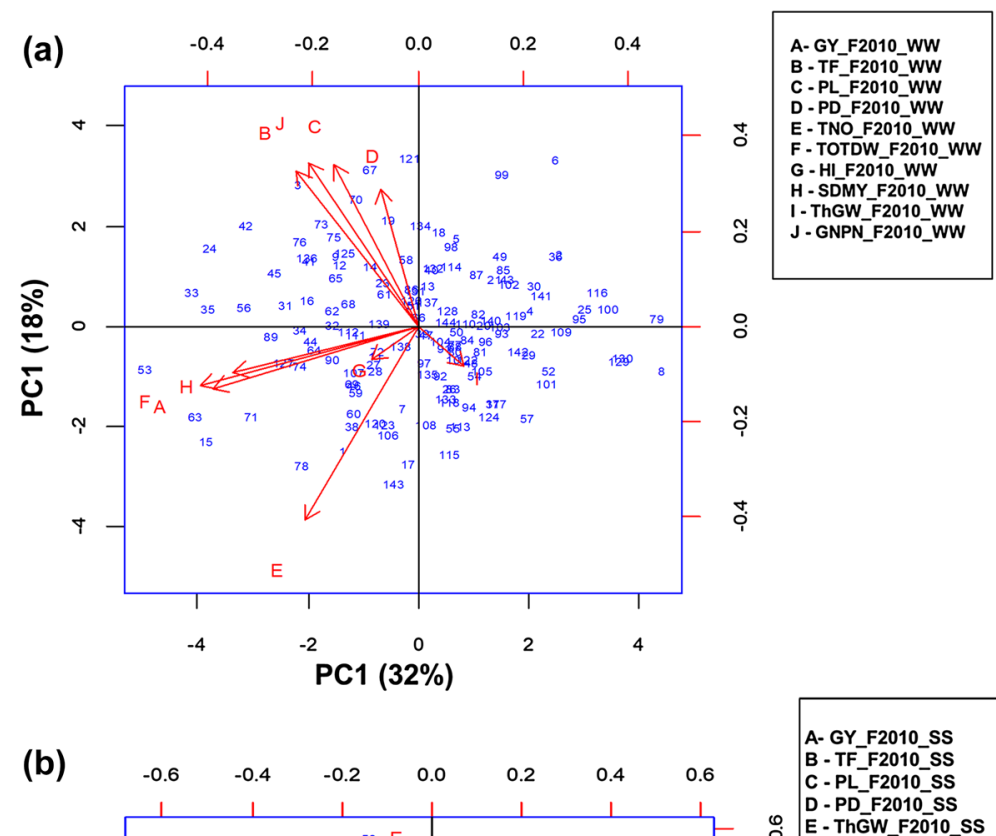

A- GY_F2010_SS B - TF_F2010_SS D-PD F2010SS E - ThGW F2010 SS F - TNO F2010 SS G - TOTDW_F2010_SS

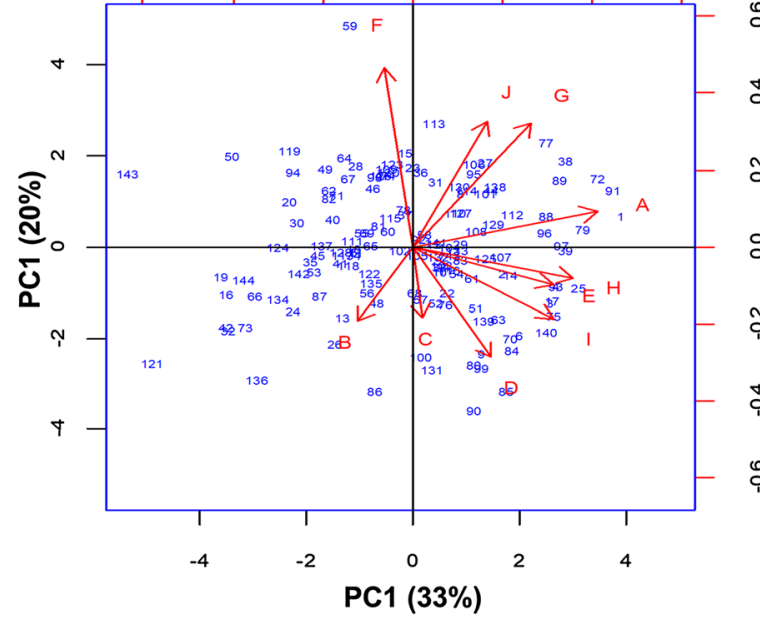

(c)

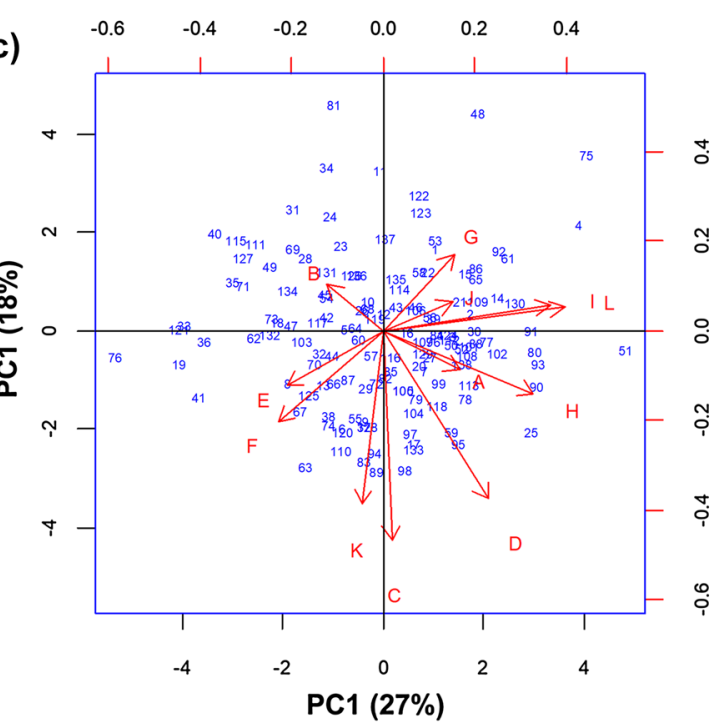

A- GY_F2010_SS B - TNO_L2010_SS C - TOTDW_L2010_SS E-T36DAS L2010 S F-T41DAS_L2010_SS G - T50DAS_L2010 SS $H-T 57 D A S$ L2010 S I - T64DAS_L2010_SS J - GY_F2011_SS K $-T E$ TE2010_SS
L-STG_L2010_SS 
Fig. 3 (continued)
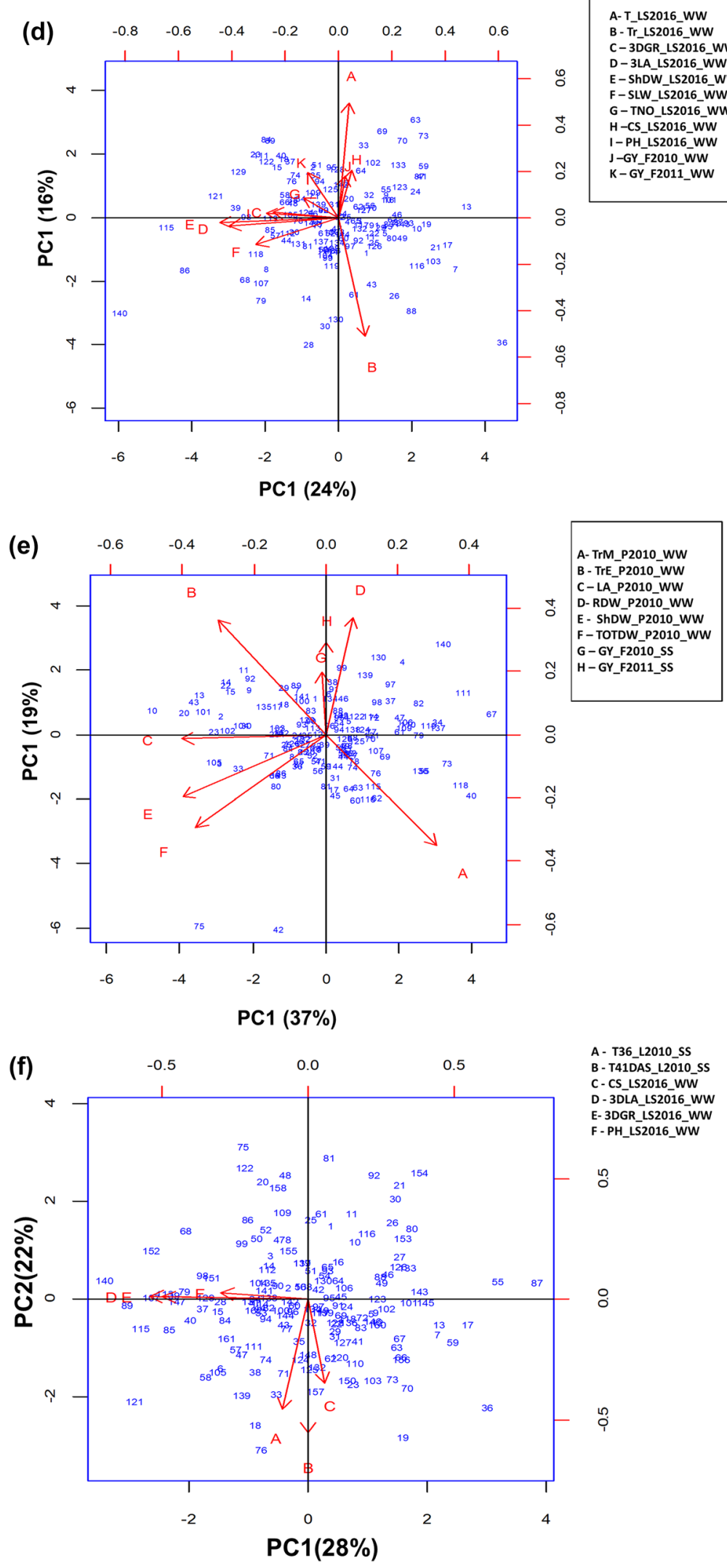
Fig. 4 QTL co-localization of the plant low-level organization traits (canopy development and water use-related traits) and high-level organization traits (biomass and grain production-related traits) on the 17 polymorphic marker region (highlighted in yellow colour) of linkage group 2 (LG02). The position of the QTLs mapped from cartographer composite interval mapping (CIM) method for the phenotypic traits are indicated either in red (positive additive effect of the alleles from 1029) or green (positive additive effect of the alleles from 1004) and the numbers in the cell represent the LOD values. $W W$ well watered, $M S$ mild water stress, $S S$ severe water stress. The environment used for phenotyping each trait is indicated by suffix letters; $\mathrm{P}$ - pot culture; LS-LeasyScan; $L$ lysimeter and $\mathrm{F}$-field. Refer to Table 1 for the acronyms of the traits
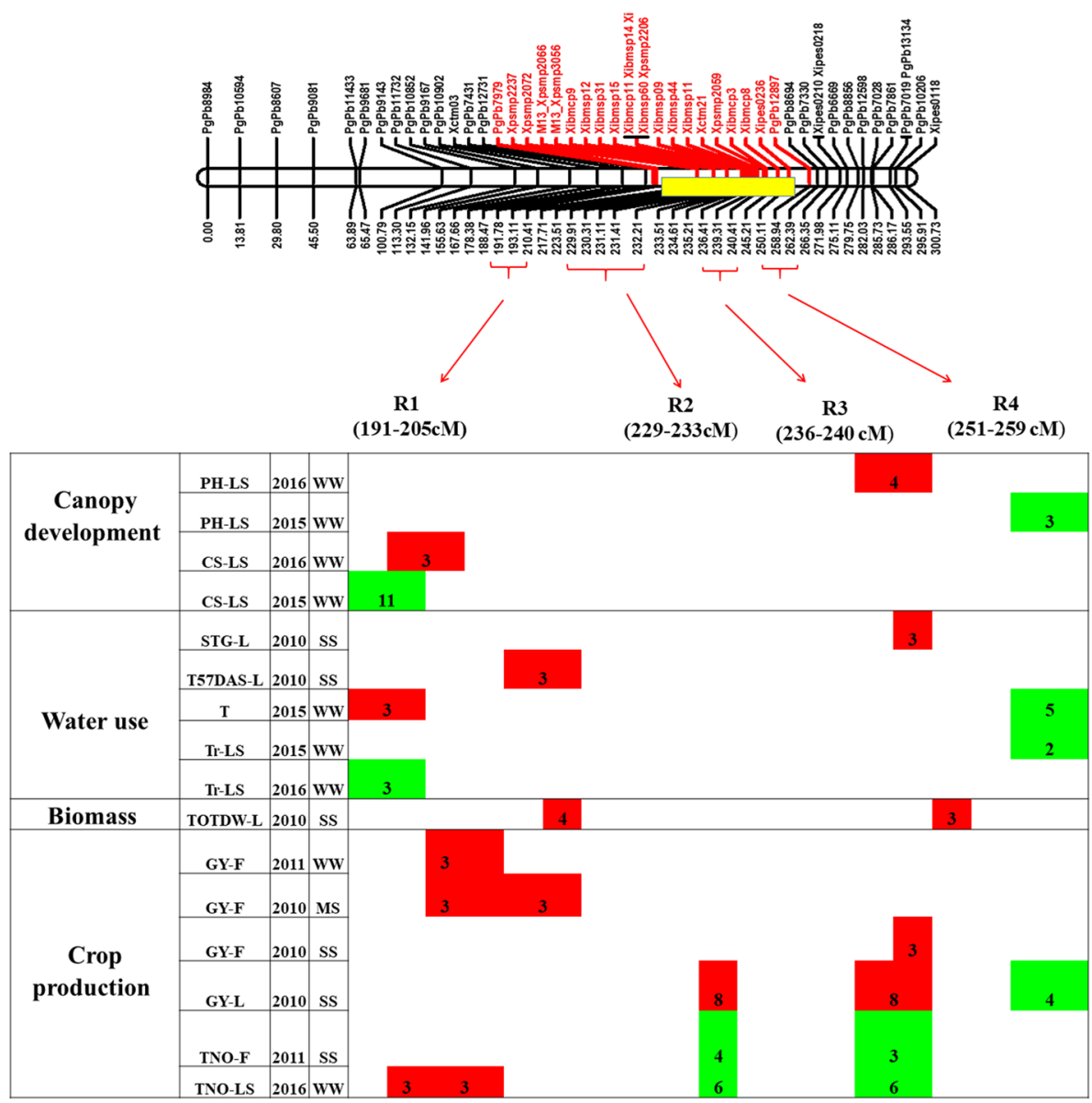

water extraction from the soil profile and indirectly the water availability for the grain filling period, with severe consequences on grain yield under water stress. Similarly, canopy structure traits were closely related to plant water use and productivity traits under favourable environments. Using a QTL co-localization approach, four sub-regions were identified within the earlier identified LG02 "drought tolerance" QTL region (Yadav et al. 2002, 2004) showing a high degree of co-location between water use/canopy structure traits and agronomic traits. These four QTL regions encompassed variability in traits across levels of plant organization and these were phenotyped in specific experimental systems (canopy development and water use-related traits; biomass and agronomic performance related). Their common genetic co-localization allowed us to speculate on their functional association.

\section{Main QTL regions detected}

We were able to trace back the locations of QTLs for similar traits documented in RIL populations before (Yadav et al. 2002, 2004; Bidinger et al. 2007; Kholova et al. 2012; Kakkera et al. 2015) and these fell into the regions documented here; i.e. traits from canopy development (leaf area), water use ( $T, T r$ ), biomass (TOTDW), and crop production (GY, details in Supplementary Table 5). The plant traits related to canopy development and water use mapped mostly in R1, R3, and R4, while plant traits related to biomass and grain production were mapped in R1, R2 and R3 and R4 positions (Fig. 4). Therefore, regions R1, R3, and R4 appeared to underlie tight trait relationship across scales of biological complexity with traits measured across different phenotyping systems, while R2 appeared to link grain yield and tillering in the lysimeter system.

Region R1 evidenced the co-location of QTLs for yield measured under no or limited water stress with traits related to canopy structure, tillering, and plant water use. Regions R3 and R4 evidenced co-location of QTLs for yield measured under severe stress conditions with traits related to plant water use at late stage such as stay green or $T$ and Tr. This suggests that traits' variability was the consequence of the presence/absence of several different loci, and each of these could relate to different simpler biological processes. In the sections that follow, we attempt to interpret how traits interact with one another in a biological sense, using co-mapping approach and multi-factorial regression (PCA). 


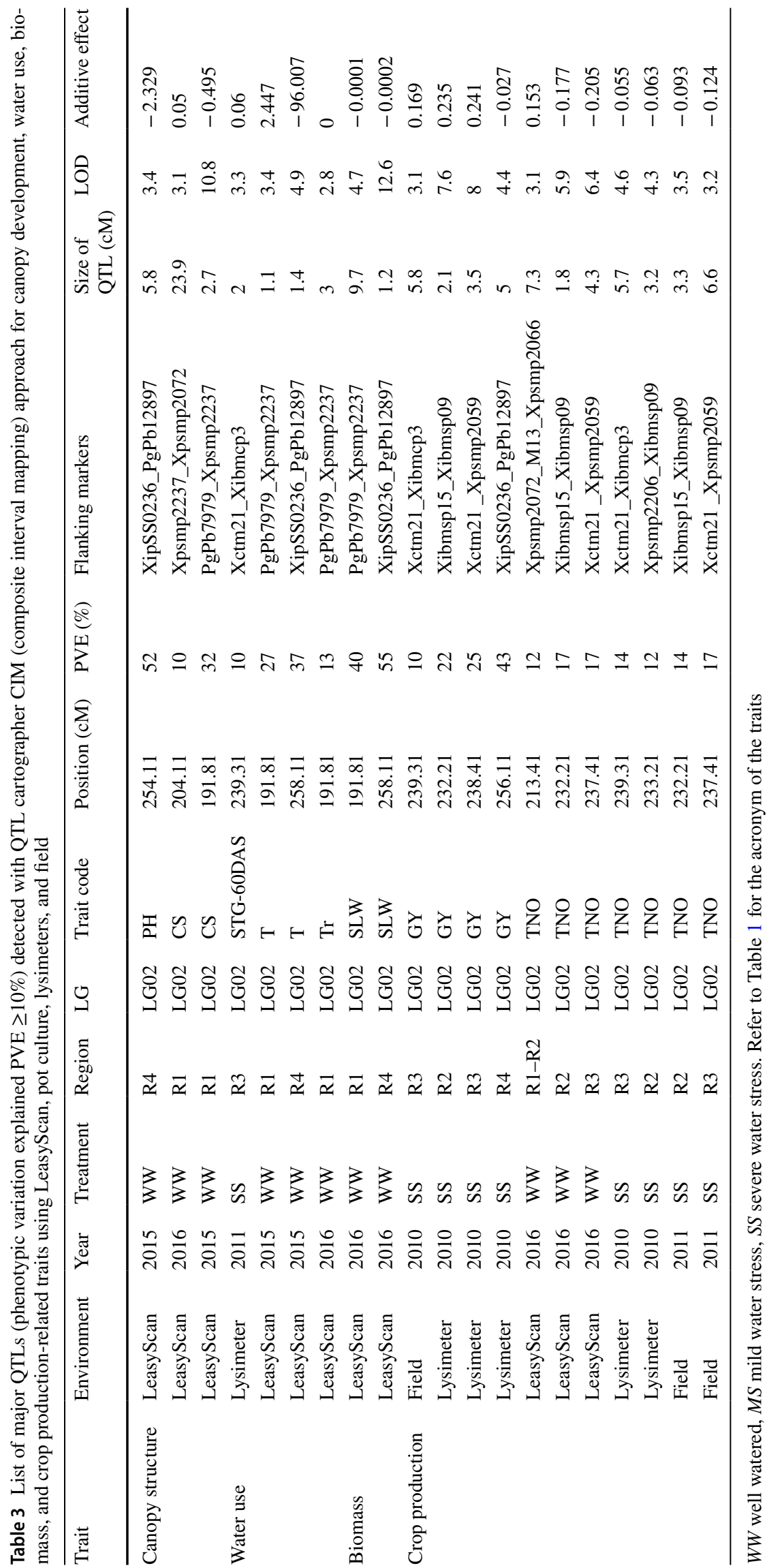


Table 4 Trait correlation analysis for the traits measured in field during 2010

\begin{tabular}{|c|c|c|c|c|c|c|c|c|c|c|c|}
\hline Trait & Stress & GY & $\mathrm{TF}$ & PL & PD & ThGW & TNO & TOTDW & $\mathrm{HI}$ & GN/PN & SDMY \\
\hline \multirow[t]{3}{*}{ GY } & WW & 1 & $0.31 * * *$ & $0.17 *$ & $0.08^{\mathrm{ns}}$ & $-0.1^{\mathrm{ns}}$ & $0.57 * * *$ & $0.9 * * *$ & $0.41 * * *$ & $0.38 * * *$ & $0.67 * * *$ \\
\hline & MS & 1 & $-0.18^{*}$ & $-0.03^{\mathrm{ns}}$ & $-0.02^{\mathrm{ns}}$ & $0.21^{\mathrm{ns}}$ & $0.55^{* * *}$ & $0.76 * * *$ & $0.67 * * *$ & $0.45^{* * *}$ & $0.42 * * *$ \\
\hline & SS & 1 & $-0.27 * *$ & $-0.07^{\mathrm{ns}}$ & $0.27 * *$ & $0.6 * * *$ & $0.07^{\mathrm{ns}}$ & $0.65^{* * *}$ & $0.86^{* * *}$ & $0.66^{* * *}$ & $0.41 * * *$ \\
\hline \multirow[t]{3}{*}{$\mathrm{TF}$} & WW & & 1 & $0.43 * * *$ & $0.17 *$ & $-0.27 * *$ & $0.02^{\mathrm{ns}}$ & $0.4 * * *$ & $-0.08^{\mathrm{ns}}$ & $0.42 * * *$ & $0.39 * * *$ \\
\hline & MS & & 1 & $0.36^{* * *}$ & $-0.03^{\mathrm{ns}}$ & $-0.4 * * *$ & $-0.2^{*}$ & $0.04^{\mathrm{ns}}$ & $-0.32 * * *$ & $0.27 * *$ & $0.13^{\mathrm{ns}}$ \\
\hline & SS & & 1 & $0.35 * * *$ & $0.14^{\mathrm{ns}}$ & $-0.35^{* * *}$ & $-0.24 * *$ & $-0.07^{\mathrm{ns}}$ & $-0.29 * *$ & $0.14^{\mathrm{ns}}$ & $0.02^{\mathrm{ns}}$ \\
\hline \multirow[t]{3}{*}{ PL } & WW & & & 1 & $0.49 * * *$ & $0.06^{\mathrm{ns}}$ & $-0.04^{\mathrm{ns}}$ & $0.23^{* *}$ & $-0.08^{\mathrm{ns}}$ & $0.17^{*}$ & $0.2^{*}$ \\
\hline & MS & & & 1 & $0.38 * * *$ & $0.01^{\mathrm{ns}}$ & $-0.14^{\mathrm{ns}}$ & $0.12^{\mathrm{ns}}$ & $-0.18^{*}$ & $0.11^{\mathrm{ns}}$ & $0.15^{\mathrm{ns}}$ \\
\hline & SS & & & 1 & $0.36^{* * *}$ & $0.04^{\mathrm{ns}}$ & $-0.19^{\mathrm{ns}}$ & $0.05^{\mathrm{ns}}$ & $-0.11^{\mathrm{ns}}$ & $0.02^{\mathrm{ns}}$ & $0.07^{\mathrm{ns}}$ \\
\hline \multirow[t]{3}{*}{ PD } & WW & & & & 1 & $0.21 * *$ & $-0.19^{*}$ & $0.06^{\mathrm{ns}}$ & $0.03^{\mathrm{ns}}$ & $0.12^{\mathrm{ns}}$ & $0.06^{\mathrm{ns}}$ \\
\hline & MS & & & & 1 & $0.46^{* * *}$ & $-0.33 * * *$ & $-0.06^{\mathrm{ns}}$ & $0.06^{\mathrm{ns}}$ & $-0.01^{\mathrm{ns}}$ & $-0.09^{\mathrm{ns}}$ \\
\hline & SS & & & & 1 & $0.36^{* * *}$ & $-0.38 * * *$ & $0.17^{\mathrm{ns}}$ & $0.23 * *$ & $0.33 * * *$ & $0.07^{\mathrm{ns}}$ \\
\hline \multirow[t]{3}{*}{ ThGW } & WW & & & & & 1 & $-0.22 * *$ & $-0.13^{\mathrm{ns}}$ & $-0.01^{\mathrm{ns}}$ & $-0.48^{* * *}$ & $0.01^{\mathrm{ns}}$ \\
\hline & MS & & & & & 1 & $-0.12^{\mathrm{ns}}$ & $0.03^{\mathrm{ns}}$ & $0.34 * * *$ & $-0.32 * * *$ & $-0.02^{\mathrm{ns}}$ \\
\hline & SS & & & & & 1 & $-0.3^{* * *}$ & $0.22 * *$ & $0.65^{* * *}$ & $0.19^{*}$ & $0.09^{\mathrm{ns}}$ \\
\hline \multirow[t]{3}{*}{ TNO } & WW & & & & & & 1 & $0.57 * * *$ & $0.1^{\mathrm{ns}}$ & $-0.35^{* * *}$ & $0.39 * * *$ \\
\hline & MS & & & & & & 1 & $0.55^{* * *}$ & $0.21^{*}$ & $-0.25^{* *}$ & $0.36 * * *$ \\
\hline & SS & & & & & & 1 & $0.31 * * *$ & $-0.09^{\mathrm{ns}}$ & $-0.46 * * *$ & $0.23 * *$ \\
\hline \multirow[t]{3}{*}{ TOTDW } & WW & & & & & & & 1 & $0^{\mathrm{ns}}$ & $0.32 * * *$ & $0.88 * * *$ \\
\hline & MS & & & & & & & 1 & $0.08^{\mathrm{ns}}$ & $0.31 * * *$ & $0.85^{* * *}$ \\
\hline & SS & & & & & & & 1 & $0.26 * *$ & $0.34 * * *$ & $0.89 * * *$ \\
\hline \multirow[t]{3}{*}{ HI } & WW & & & & & & & & 1 & $0.24 * *$ & $-0.3 * * *$ \\
\hline & MS & & & & & & & & 1 & $0.34 * * *$ & $-0.27 * * *$ \\
\hline & SS & & & & & & & & 1 & $0.61^{* * *}$ & $0.01^{\mathrm{ns}}$ \\
\hline \multirow[t]{3}{*}{$\mathrm{GNPN}^{-1}$} & WW & & & & & & & & & 1 & $0.21 *$ \\
\hline & MS & & & & & & & & & 1 & $0.14^{\mathrm{ns}}$ \\
\hline & SS & & & & & & & & & 1 & $0.22 * *$ \\
\hline \multirow[t]{3}{*}{ SDMY } & WW & & & & & & & & & & 1 \\
\hline & MS & & & & & & & & & & 1 \\
\hline & SS & & & & & & & & & & 1 \\
\hline
\end{tabular}

$W W$ well watered, $M S$ mild water stress, $S S$ severe water stress. Refer to Table 1 for the acronym of the traits

$* * * p<0.001, * * p<0.01, * p<0.05, n s$ non-significant

\section{Water extraction during grain filling increases yield under water stress}

Under SS in the field, the PCA showed that GY was positively associated with the water extracted during grain filling (lysimeters; T50, 57 and 64DAS) and also to the stay-green scores (STG; lysimeters). This was also seen by the colocation of stay-green QTL and grain yield both in the field and in the lysimeters in the R3 genomic region of LG02. The region $\mathrm{R} 2$, found specifically from lysimeter data, also showed evidence of a genetic linkage between traits reflecting water availability during grain filling and grain yield. There are indeed reports stating that the water extracted during grain filling led to increase in yield across a range of crops (Manschadi et al. 2006; Kirkegaard et al. 2007; Vadez et al. 2013a). The expression of these traits during later plant growth (i.e. the positive association between GY and the water extracted during grain filling at 50,57, and 64DAS, and then the expression of a stay-green phenotype with the positive association to water extracted at grain filling) might have been pre-determined by the magnitude of saving water earlier. Figure $3 c$ indeed shows that water extraction at vegetative stage was in complete opposition to water extraction during grain filling, therefore suggesting that plant size could have been a strong determinant of these different water use patterns. Large plants would indeed tend to extract more water early in the crop cycle, as reported earlier in other crops and situations (Vadez et al. 2011; Zaman-Allah et al. 2011a). Previous work in chickpea and pearl millet (ZamanAllah et al. 2011b; Vadez et al. 2013a) had shown that a low Tr under high VPD at the vegetative stage would also be a way to make more water available for the grain filling part 
Table 5 Trait correlation analysis for the traits measured in field during 2011

\begin{tabular}{|c|c|c|c|c|c|c|c|c|c|c|c|}
\hline Trait & Stress & GY & TF & PL & PD & TNO & TOTDW & HI & SDMY & ThDW & $\mathrm{GNPN}^{-1}$ \\
\hline \multirow[t]{3}{*}{ GY } & WW & 1 & $0.23 * *$ & $0.1^{\mathrm{ns}}$ & $0.11^{\mathrm{ns}}$ & $0.64 * * *$ & $0.88 * * *$ & $0.46 * * *$ & $0.71 * * *$ & $-0.17^{\mathrm{ns}}$ & $0.4 * * *$ \\
\hline & MS & 1 & $-0.35^{* * *}$ & $-0.05^{\mathrm{ns}}$ & $0.1^{\mathrm{ns}}$ & $0.32 * * *$ & $0.73 * * *$ & $0.71 * * *$ & $0.44 * * *$ & $0.43 * * *$ & $0.39 * * *$ \\
\hline & SS & 1 & $-0.41 * * *$ & $-0.18^{*}$ & $0.22 * *$ & $0.24 * *$ & $0.74 * * *$ & $0.86 * * *$ & $0.49 * * *$ & $0.44 * * *$ & $0.61 * * *$ \\
\hline \multirow[t]{3}{*}{$\mathrm{TF}$} & WW & & 1 & $0.27 * *$ & $0.15^{\mathrm{ns}}$ & $0.17^{*}$ & $0.35^{* * *}$ & $-0.15^{\mathrm{ns}}$ & $0.34 * * *$ & $-0.35^{* * *}$ & $0.3 * * *$ \\
\hline & MS & & 1 & $0.47 * * *$ & $0.18^{*}$ & $-0.09^{\mathrm{ns}}$ & $0.06^{\mathrm{ns}}$ & $-0.6 * * *$ & $0.24 * *$ & $-0.53 * * *$ & $0.14^{\mathrm{ns}}$ \\
\hline & SS & & 1 & $0.31 * * *$ & $0.05^{\mathrm{ns}}$ & $-0.08^{\mathrm{ns}}$ & $-0.15^{\mathrm{ns}}$ & $-0.47 * * *$ & $-0.01^{\mathrm{ns}}$ & $-0.42 * * *$ & $-0.09^{\mathrm{ns}}$ \\
\hline \multirow[t]{3}{*}{ PL } & WW & & & 1 & $0.34 * * *$ & $0.02^{\mathrm{ns}}$ & $0.23 * *$ & $-0.19 *$ & $0.24 * *$ & $0.02^{\mathrm{ns}}$ & $0.06^{\mathrm{ns}}$ \\
\hline & MS & & & 1 & $0.35 * * *$ & $-0.04^{\mathrm{ns}}$ & $0.14^{\mathrm{ns}}$ & $-0.22 * *$ & $0.19 *$ & $-0.1^{\mathrm{ns}}$ & $0.06^{\mathrm{ns}}$ \\
\hline & SS & & & 1 & $0.13^{\mathrm{ns}}$ & $-0.23 * *$ & $-0.09^{\mathrm{ns}}$ & $-0.17 *$ & $-0.07^{\mathrm{ns}}$ & $-0.13^{\mathrm{ns}}$ & $0.07^{\mathrm{ns}}$ \\
\hline \multirow[t]{3}{*}{ PD } & WW & & & & 1 & $-0.31 * * *$ & $0.16^{*}$ & $-0.05^{\mathrm{ns}}$ & $0.22 * *$ & $0.22 * *$ & $0.3^{* * *}$ \\
\hline & MS & & & & 1 & $-0.29 * * *$ & $0.07^{\mathrm{ns}}$ & $0.09^{\mathrm{ns}}$ & $0.09^{\mathrm{ns}}$ & $0.26 * *$ & $0.19^{*}$ \\
\hline & SS & & & & 1 & $-0.36 * * *$ & $0.01^{\mathrm{ns}}$ & $0.31 * * *$ & $-0.1^{\mathrm{ns}}$ & $0.31 * * *$ & $0.32 * * *$ \\
\hline \multirow[t]{3}{*}{ TNO } & WW & & & & & 1 & $0.63 * * *$ & $0.15^{\mathrm{ns}}$ & $0.45^{* * *}$ & $-0.38 * * *$ & $-0.2^{*}$ \\
\hline & MS & & & & & 1 & $0.55 * * *$ & $-0.08^{\mathrm{ns}}$ & $0.37 * * *$ & $-0.29 * * *$ & $-0.44 * * *$ \\
\hline & SS & & & & & 1 & $0.6^{* * *}$ & $-0.09^{\mathrm{ns}}$ & $0.57 * * *$ & $-0.28 * * *$ & $-0.35 * * *$ \\
\hline \multirow[t]{3}{*}{ TOTDW } & WW & & & & & & 1 & $0.01^{\mathrm{ns}}$ & $0.92 * * *$ & $-0.11^{\mathrm{ns}}$ & $0.24 * *$ \\
\hline & MS & & & & & & 1 & $0.07^{\mathrm{ns}}$ & $0.87 * * *$ & $0^{\mathrm{ns}}$ & $0.23 * *$ \\
\hline & SS & & & & & & 1 & $0.31 * * *$ & $0.9 * * *$ & $0.12^{\mathrm{ns}}$ & $0.25 * *$ \\
\hline \multirow[t]{3}{*}{ HI } & WW & & & & & & & 1 & $-0.21^{*}$ & $-0.15^{\mathrm{ns}}$ & $0.43 * * *$ \\
\hline & MS & & & & & & & 1 & $-0.23 * *$ & $0.62 * * *$ & $0.34 * * *$ \\
\hline & SS & & & & & & & 1 & $0.03^{\mathrm{ns}}$ & $0.53 * * *$ & $0.67 * * *$ \\
\hline \multirow[t]{3}{*}{ SDMY } & WW & & & & & & & & 1 & $0.03^{\mathrm{ns}}$ & $0.17 *$ \\
\hline & MS & & & & & & & & 1 & $-0.09^{\mathrm{ns}}$ & $0.19^{*}$ \\
\hline & SS & & & & & & & & 1 & $0.01^{\mathrm{ns}}$ & $0.06^{\mathrm{ns}}$ \\
\hline \multirow[t]{3}{*}{ ThGW } & WW & & & & & & & & & 1 & $-0.47 * * *$ \\
\hline & MS & & & & & & & & & 1 & $-0.09^{\mathrm{ns}}$ \\
\hline & SS & & & & & & & & & 1 & $0.01^{\mathrm{ns}}$ \\
\hline \multirow[t]{3}{*}{$\mathrm{GNPN}^{-1}$} & WW & & & & & & & & & & 1 \\
\hline & MS & & & & & & & & & & 1 \\
\hline & SS & & & & & & & & & & 1 \\
\hline
\end{tabular}

$W W$ well watered, $M S$ mild water stress, $S S$ severe water stress. Refer to Table 1 for the acronym of the traits

$* * * p<0.001, * * p<0.01, * P<0.05, n s$ non-significant

and eventually lead to higher yield under water stress. On the contrary, in this set of genetic material, we found only a positive relationship, from co-location in $\mathrm{R} 4$, and in the PCA analysis, between Tr and higher yield under stress conditions, and no relationship between $\operatorname{Tr}$ and the availability of water during grain filling. Our interpretation is that $\operatorname{Tr}$ did not play a significant water-saving role in this genetic material and a consequence was that TE was not a major determinant of yield variations.

\section{Canopy structure boosts plant water use and yield under favourable conditions}

In the paragraph above, we showed the importance of limited early plant water use for making more water available post-anthesis and then boosting production under severe water stress. The early water use traits (lysimeters) were also found to be associated with CS (in LeasyScan; Fig. 3f) in this particular fine-mapping population. These results were confirmed in the QTL co-mapping analysis, where the QTL for CS (WW) was found to be co-located with the QTLs for GY under no or limited stress conditions and for tiller numbers. A high CS value represents a high residual in the relationship between the 3D leaf area and the projected area, which can be taken as a proxy for low degree of erectness of the canopy. Our interpretation is that high CS would also contribute to more leaf cover that may result in more transpiration and vice versa. The high canopy cover would then increase leaf mutual shading and therefore lead to decreased overall transpiration rate. Therefore, this result not only emphasizes the importance of canopy organization in space for crop early water use, but also highlights its importance 
for GY as CS determines the intensity of light penetration (Sampson and Smith 1993) and photosynthesis (Pendleton et al. 1968; Intrieri et al. 1997; Stewert et al. 2003; Hammer et al. 2008; Sharma et al. 2013).

\section{High tillering and biomass accumulation lead to higher grain yield under mild/no stress, but not under severe water stress}

Under mild or no stress situation, the crop grain production was the consequence of the ability of plants to accumulate biomass and partition the stored assimilates into the grains (Liang et al. 2009). This was evidenced in the PCA where the grain production $(\mathrm{GY})$ under WW was very well related to TNO under WW, indicating that grain filling in tillers under WW would add to the GY from the main shoot panicle. The PCA analysis also showed that under WW, TOTDW was related to GY. This was also supported by the QTL co-mapping analysis, where the QTL for TNO co-located with the QTL for GY from field under WW and MS between R1 and R2 and also with GY under SS from field in R3 and lysimeters in R2 and R3. Similarly, the QTL for TOTDW under WW in R3 co-located with GY (MS). Here, it should be noticed that while the alleles from both ICMR1004 and ICMR1029 contributed to crop production traits under non-stress conditions, only the allele from 1029 specifically contributed to crop production traits under severe water stress. Earlier studies report the co-localization of QTLs for biomass, GY, and component traits (Liang et al. 2009; Shi et al. 2009; Matsubara et al. 2016). QTLs for biomass-related traits within the pearl millet LG02 have been reported earlier (Kholova et al. 2012; Kakkera et al. 2015). In fact, seminal work on pearl millet adaptation to terminal water stress (Bidinger et al. 1987) showed that yield under stress was in part, besides flowering time, determined by the yield potential. Our interpretation is that the yield potential had an important weight in the yield determination of this population, even under stress conditions.

Under severe water stress, the results were opposite. The PCA analysis showed that tiller number either measured in the field or in the lysimeters were in opposite direction to grain yield. We could not find any linkage from the co-localization analysis suggesting the QTLs for TNO under SS were not as useful as under WW. Such a result would be expected: under severe stress, the production of additional tillers initially costs water, while the grain filling of these additional tillers can fail totally under severe terminal stress. Therefore, producing tillers would be a worthy strategy in situations where there is no water limitation, but a drawback under water limitation where the investment in tillers would not be rewarded by grain produced from these tillers (Mackill et al. 1996). Therefore, tiller contribution to GY depended largely on the water regime and could explain why several
QTLs for tillering were found (R1, R2, and R3) each related to different secondary traits.

\section{Crop improvement strategy}

Our study clearly demonstrated that some traits which support crop production in one environment might bring production penalty in another (Tardieu 2012; Vadez et al. 2013b; Kholova et al. 2013). In environments with unlimited water access, biomass and tiller production led to increase in water use and these traits were strongly anchored on R1, $\mathrm{R} 2, \mathrm{R} 3$, and $\mathrm{R} 4$ genetic regions.

On the contrary, in severely water-limited environments, where water can be stored in the soil profile, crop production benefitted from less vigorous growth/smaller canopy (Vadez et al. 2013b). In the current study, a restricted transpiration rate under high VPD did not appear to play such a significant role. In this, under SS, most of the traits on crop production were contributed by the parent ICMR1029. To use these traits in crop improvement programs, more work would be needed to quantify the site-specific frequency of the different types of water stress conditions, as done earlier in other crops (Vadez et al. 2013c; Kholova et al. 2014).

Overall, this study demonstrated that crop production was tightly linked to traits at a lower level of plant organization, in a manner that was dependent on the stress intensity. Several genetic regions showed co-location of these traits. Additional regions for similar traits have been recently identified (Aparna et al. 2015; Aparna et al. personal communication). These could be used for the breeding of cultivars fitted to specific stress conditions, provided that a suitable breeding strategy is adopted to most efficiently combine alleles of small effects. In that respect, this work has also shown the value of combining an analysis at different levels, physiological with the PCA analysis, genetic with the co-localization work, but also targeting phenotypes at different levels of plant organization.

Author contribution statement MT, JK, KS, VV, and BR performed phenotyping. DS genotyped the molecular markers with RY. CTH developed the fine-mapping population. RKS provided the seed material for the experimental work. RB prepared the files of configuration (LeasyScan experiments) and randomization (LeasyScan, lysimeters, and field experiments). MT carried out the analysis, prepared the tables and figures, and wrote the manuscript. JK and $\mathrm{VV}$ conceived the study, provided advice on analysis and interpreted the results. JK, VV, MT, DS, and TT reviewed the paper.

Acknowledgements Work was funded by a grant from the USAIDFeed the Future Innovation Lab-Development of Abiotic Stress 
Tolerant Millet for Africa and South Asia. The authors are thankful to Mr. N. Pentaiah, Mr. PVD. Maheshwar Rao, and Mr. M. Anjaiah for their expert technical support. The authors thank an anonymous reviewer for the valuable suggestions. Funding was provided by Climate Resilient Pearl Millet.

\section{Compliance with ethical standards}

Conflict of interest The authors declare that they have no conflict of interest.

\section{References}

Aparna K, Nepolean T, Srivastava RK, Kholova J, Rajaram V, Kumar S, Rekha B, Senthilvel S, Hash CT, Vadez V (2015) Quantitative trait loci associated with constitutive traits control water use in pearl millet [Pennisetum glaucum (L). R.Br.]. Plant Biol 17(5):1073-1084

Banziger M, Cooper M (2001) Breeding for low input conditions and consequences for participatory plant breeding examples from tropical maize and wheat. Euphytica 122(3):503-519

Bidinger FR, Mahalakshmi V, Durga Prasada Rao G (1987) Assessment of drought resistance in pearl millet [Pennisetum americanum (L). Leeke]: II Estimation of genotype response to stress. Aust J Agric Res 38:49-59

Bidinger FR, Serraj R, Rizvi SMH, Howarth C, Yadav RS, Hash CT (2005) Field evaluation of drought tolerance QTL effects on phenotype and adaptation pearl millet [Pennisetum glaucum $(\mathrm{L})$. R.Br.] topcross hybrids. Field Crops Res 94:14-32

Bidinger FR, Nepolean T, Hash CT, Yadav RS, Howarth CJ (2007) Quantitative trait loci for grain yield in pearl millet under variable post flowering moisture conditions. Crop Sci 47:969-980

Gupta SK, Rai KN, Singh P, Ameta VL, Gupta Suresh K, Jayalekha AK, Mahala RS, Pareek S, Swami ML, Verma YS (2015) Seed set variability under high temperatures during flowering period in pearl millet [Pennisetum glaucum (L). R.Br.]. Field Crops Res 171:41-53

Hammer GL, Dong Z, McLean G, Doherty A, Messina C, Schussler J, Zinselmeier C, Paszkiewicz S, Cooper M (2008) Can changes in canopy and/or root system architecture explain historical maize yield trends in the US corn belt? Crop Sci 49:299-312

Intrieri C, Poni S, Rebucci B, Magnanini E (1997) Effects of canopy manipulations on whole-vine photosynthesis: results from pot and field experiments. Vitis 36:167-173

Kakkera A, Nepolean T, Srivastava RK, Kholova J, Rajaram V, Kumar S, Baddam R, Senthilvel S, Hash CT, Vadez V (2015) Quantitative trait loci associated with constitutive traits control water use in pearl millet [Pennisetum glaucum (L). R.Br.]. Plant Biol 17(5):1073-1084

Kholova J, Nepolean T, Hash CT, Supriya A, Rajaram V, Senthilvel S, Aparna K, Yadav RS, Vadez V (2012) Water saving traits co map with a major terminal tolerance quantitative trait locus in pearl millet [Pennisetum glaucum (L). R.Br.]. Mol Breed 30:1337-1353

Kholova J, McLean G, Vadez V, Craufaud P, Hammer GL (2013) Drought stress characterisation of post rainy (rabi) sorghum in India. Field Crops Res 141:38-46

Kholova J, Murugesan T, Kaliamoorthy S, Malayee S, Baddam R, Hammer GL, McLean G, Despande SP, Hash CT, Craufaud P, Vadez V (2014) Modelling the effect of plant water use traits on yield and stay-green expression in sorghum. Funct Plant Biol 41:1019-1034

Kholova J, Zindy P, Malayee S, Baddam R, Murugesan T, Kaliamoorthy S, Hash CT, Votrubová O, Soukup A, Kocová M, Niang M,
Vadez V (2016) Component traits of plant water use are modulated by vapour pressure deficit in pearl millet (Pennisetum glaucum (L.) R.Br.). Funct Plant Biol. https://doi.org/10.1071/FP151 15

Kirkegaard JA, Lilley JM, Howe GN, Graham JM (2007) Impact of subsoil water use on wheat yield. Aust J Agric Res 58:303-315

Krishnamurthy L, Serraj R, Rai KN, Hash CT, Dakeel AJ (2007) Identification of pearl millet [Pennisetum glaucum (L.) R.Br] lines tolerant to soil salinity. Euphytica 158:179-188

Liang Y, Zhang K, Zhao L, Liu B, Meng Q, Tian J, Zhao S (2009) Identification of chromosome regions conferring dry matter accumulation and photosynthesis in wheat (Triticum aestivum L.). Euphytica 171:145-156

Mackill DJ, Coffman WR, Garrity DP (1996) Rainfed lowland rice improvement. International Rice Research Intitute, Manila

Mahalakshmi V, Bidinger FR, Raju DS (1987) Effect of timing of water deficit in pearl millet [Pennisetum americanum (L). Leeke]. Field Crops Res 15(3-4):327-339

Manschadi AM, Christopher JT, Peter de Voil P, Hammer GL (2006) The role of root architecture traits in adaptation of wheat to water limited environments. Funct Plant Biol 33:823-837

Matsubara K, Yamamoto E, Kobayashi N, Ishii T, Tanaka J, Tsunematsu H, Yoshinaga S, Matsumura O, Yonemaru J, Mizobuchi R, Yamamoto T, Kato H, Yano M (2016) Improvement of rice biomass yield through QTL based selection. Plos One. https:// doi.org/10.1371/journal.pone.0151830

Pendleton JW, Smith GE, Winter SR, Johnston TJ (1968) Field investigations of the relationships of leaf angle in corn (Zea mays L.) to grain yield and apparent photosynthesis. Agron J 60:422-424

Sampson DA, Smith FW (1993) Influence of canopy architecture on light penetration in lodgepole pine (Pinus contorta var. latifolia) forests. Agric For Meteorol 64:63-79

Sehgal D, Rajaram V, Armstead IP, Vadez V, Yadav YP, Hash CT, Yadav RS (2012) Integration of gene based markers in pearl millet genetic map for identification of candidate genes underlying drought tolerance quantitative trait loci. BMC Plant Biol 12:9

Serraj R, Hash CT, Rizvi SMH, Sharma A, Yadav RS, Bidinger FR (2005) Recent advances in marker-assisted selection for drought tolerance in pearl millet. Plant Prod Sci 8:334-337

Sharma D, Sanghera GS, Sahu P, Sahu P, Parikh M, Sharma B, Bhandarkar S, Chaudhari PR, Jena BK (2013) Tailoring rice plants for sustainable yield through ideotype breeding and physiological interventions. Afr J Agric Res 8:5004-5019

Shi J, Li R, Qiu D, Jiang C, Long Y, Morgan C, Bancroft I, Zhao J, Meng J (2009) Unraveling the complex trait of crop yield with quantitative trait loci mapping in Brassica napus. Genetics 182:851-861

Stam P (1993) Construction of integrated genetic linkage maps by means of a new computer package: join map. Plant J 3:739-744

Stewert DW, Costa C, Dwyer LM, Smith DL, Hamilton RI, Ma BL (2003) Canopy structure, light interception, and photosynthesis in maize. Agron J 95:1465-1474

Tardieu F (2012) Any trait or trait related allele can confer drought tolerance: just design the right drought scenario. J Exp Bot 63:25-31

Vadez V, Ratnakumar P (2016) High transpiration efficiency increases pod yield under intermittent drought in dry and hot atmospheric conditions but less so under wetter and cooler conditions in groundnut (Arachis hypogaea (L.)). Field Crops Res 193:16-23

Vadez V, Krishnamurthy L, Serraj R, Gaur PM, Upadhyaya HD, Hoisington DA, Varshney RK, Turner NC, Siddique KHM (2007) Large variation in salinity tolerance in chickpea is explained by differences in sensitivity at the reproductive stage. Field Crops Res 104:123-129

Vadez V, Krishnamurthy L, Hash CT, Upadhyaya HD, Borrell AK (2011) Yield, Transpiration efficiency, and water use variations 
and their relationships in sorghum reference collection. Crop Pasture Sci 62:645-655

Vadez V, Kholova J, Yadav RS, Hash CT (2013a) Small temporal differences in water uptake among varieties of pearl millet [Pennisetum glaucum (L). R.Br.] are critical for grain yield under terminal drought. Plant Soil 371:447-462

Vadez V, Kholova J, Zaman-Allah M, Belko N (2013b) Water: the most important "molecular" component of water stress tolerance research. Funct Plant Biol 40:1310-1322

Vadez V, Soltani A, Sinclair TR (2013c) Crop simulation analysis of phenological adaptation in chickpea to different altitudes of India. Field Crops Res 146:1-9

Vadez V, Kholova J, Hummel G, Zhokhavets U, Gupta SK, Hash CT (2015) LeasyScan: a novel concept combining 3D imaging and lysimetry for high-throughput phenotyping of traits controlling water budget. J Exp Bot. https://doi.org/10.1093/jxb/erv251

Sivasakthi K, Thudi M, Tharanya M, Kale SM, Kholová J, Halime MH, Jaganathan D, Baddam R, Thirunalasundari T, Gaur PM, Varshney RK, Vadez V (2018) Plant vigour QTLs co-map with an earlier reported QTL hotspot for drought tolerance while water saving QTLs map in other regions of the chickpea genome. BMC Plant Biol 18(1):29

Yadav RS, Hash CT, Bidinger FR, Cavan GP, Howarth CJ (2002) Quantitative trait loci associated with traits determining grain and stover yield in pearl millet under terminal drought-stress conditions. Theor Appl Genet 104:67-83

Yadav RS, Bidinger FR, Hash CT, Yadav YP, Yadav OP, Bhatnagar SK, Howarth CJ (2003) Mapping and characterization of QTL $\times$ $E$ interactions for traits determining grain and stover yield in pearl millet. Theor Appl Genet 106:512-520

Yadav RS, Hash CT, Bidinger FR, Devos KM, Howarth CJ (2004) Genomic regions associated with grain yield and aspects of postflowering drought tolerance in pearl millet across stress environments and tester background. Euphytica 136:265-277

Yadav RS, Sehgal D, Vadez V (2010) Using genetic mapping and genomics approaches in understanding and improving drought tolerance in pearl millet. J Exp Bot. https://doi.org/10.1093/jxb/ erq265

Zaman-Allah M, Jenkinson DM, Vadez V (2011a) A conservative pattern of water use, rather than deep or profuse rooting, is critical for the terminal drought tolerance of chickpea. J Exp Bot 62:4239-4252

Zaman-Allah M, Jenkinson D, Vadez V (2011b) Chickpea genotypes contrasting for seed yield under terminal drought stress in the field differ for traits related to the control of water use. Funct Plant Biol 38:270-281 